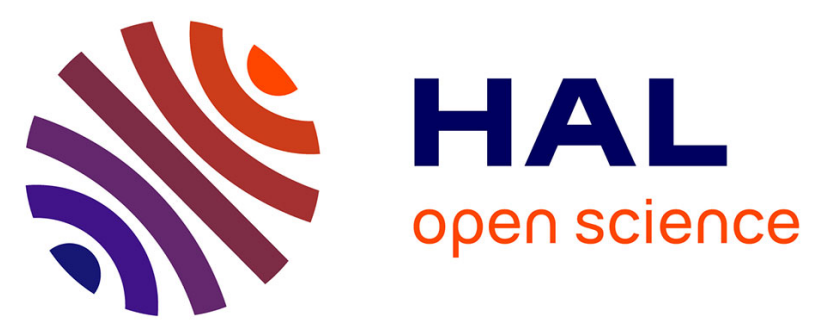

\title{
A turning-point in the evolution of the Variscan orogen: the ca. 325 Ma regional partial-melting event of the coastal South Armorican domain (South Brittany and Vendée, France)
}

\author{
Romain Augier, Flavien Choulet, Michel Faure, Paul Turrillot
}

\section{To cite this version:}

Romain Augier, Flavien Choulet, Michel Faure, Paul Turrillot. A turning-point in the evolution of the Variscan orogen: the ca. 325 Ma regional partial-melting event of the coastal South Armorican domain (South Brittany and Vendée, France). Bulletin de la Société Géologique de France, 2015, 186 (2-3), pp.63-91. 10.2113/gssgfbull.186.2-3.63 . insu-01140374

\author{
HAL Id: insu-01140374 \\ https://hal-insu.archives-ouvertes.fr/insu-01140374
}

Submitted on 15 Feb 2021

HAL is a multi-disciplinary open access archive for the deposit and dissemination of scientific research documents, whether they are published or not. The documents may come from teaching and research institutions in France or abroad, or from public or private research centers.
L'archive ouverte pluridisciplinaire HAL, est destinée au dépôt et à la diffusion de documents scientifiques de niveau recherche, publiés ou non, émanant des établissements d'enseignement et de recherche français ou étrangers, des laboratoires publics ou privés. 


\title{
A turning-point in the evolution of the Variscan orogen: the ca. 325 Ma regional partial-melting event of the coastal South Armorican domain (South Brittany and Vendée, France)
}

\author{
Romain AUGIER ${ }^{1,2,3}$, Flavien CHOULET ${ }^{4}$, Michel FAURE $^{1,2,3}$ and PAUL TURRILlOT ${ }^{1,2,3}$
}

Keywords. - Partial-melting, Strain localisation, Gravitational collapse, U-Th/Pb on monazite, South Armorican domain

Abstract. - By drastically reducing the bulk strength of crustal materials, partial-melting is one of the main parameter controlling the rheological behaviour of the continental crust. With more than ca. 50\% of the outcropping surface characterised by migmatites and granites, the coastal South Armorican domain, offers an opportunity to study deep-orogenic processes and more particularly, to understand the role of partial-melting for the late-evolution of the Variscan belt. To date, time-constraints are scarce hindering the understanding of this crucial stage in the Variscan belt evolution. This pa-per provides 29 new $\mathrm{U}-\mathrm{Th} / \mathrm{Pb}$ chemical ages on monazite collected over five sampling areas consisting in migmatite domes and late regional classic plutons. Based on structural, textural and chemical criteria, three main U-Th/Pb age-groups are distinguished. The first group, settled at ca. 335-330 Ma concerns samples of restites and core-domains of the monazite crystals for most of the granite massifs. Its significance is ascribed to inherited crystallisation ages probably recording the crossing of prograde monazite forming reactions (i.e. metamorphic isograds) during increasing P-T conditions in an overall nappe-stacking context. The second group that clusters at ca. 325-320 Ma corresponds to newly formed monazite grains that crystallised from juvenile silicate melts. Ages of this group are interpreted as crystallisation ages of leucosomes after a major partial-melting event that affected the whole domain. The last ca. 320 Ma group corresponds to rim-domains of monazite crystals. It is interpreted as the emplacement age of most of the large-scale granite massifs and therefore fixes the end of the partial-melting event.

The inception and drastic generalisation of partial-melting at peak-P conditions therefore coincides with a major change in the tectonic regime recorded at regional-scale. In the lights of these results, this implies that (1) either contin-uous stacking of continental crustal units, rich in radiogenic elements, led to an increase of temperature within the orogenic wedge provoking partial-melting, the resulting drop in the crustal strength inducing collapse and lateral expan-sion of the belt, or (2) a drastic change of the boundary conditions has induced hot asthenospheric upwelling which in turn led to coeval extension and partial-melting. At a more local scale, strain benefited of the low-strength of the mag-matic bodies prior to complete crystallisation promoting intense strain localisation within the South Armorican domain large-scale laccoliths often referred to as synkinematic plutons.

Un tournant dans l'évolution de l'orogène Varisque : l'événement régional de fusion partielle à 325 Ma du domaine Sud Armoricain côtier (Bretagne Sud et Vendée, France)

Mots-clés. - Fusion partielle, Localisation de la déformation, Effondrement gravitaire, U-Th/Pb sur monazite, Domaine Sud Armoricain

Résumé. - En réduisant considérablement la résistance des matériaux crustaux, la fusion partielle est un paramètre ma-jeur contrôlant le comportement rhéologique de la croûte continentale. Avec plus de 50\% de surface d'affleurement ca-ractérisée par des migmatites et des granites, la partie côtière du domaine Sud Armoricain offre l'opportunité d'étudier les processus orogéniques profonds et plus particulièrement de cerner le rôle de la fusion partielle dans l'évolution tar-dive de la chaîne Varisque. Pour l'heure, très peu de contraintes géochronologiques sont disponibles entravant la com-préhension de cette étape cruciale dans l'évolution de la chaîne. Cette étude apporte un total de 29 nouvelles datations chimiques U-Th/Pb sur monazite provenant de cinq zones d'échantillonnage composées de dômes migmatitiques et de granites associés ou tardifs. Sur des critères structuraux, texturaux et chimiques, trois principaux groupes d'âges $\mathrm{U}-\mathrm{Th} / \mathrm{Pb}$ ont été reconnus.

Le premier groupe, principalement centré vers 335-330 Ma a été mis en évidence pour des échantillons de restites et pour les domaines de cœur des cristaux de monazite de la plupart de massifs de granite. Sa signification est attribuée à des âges de cristallisation hérités enregistrant probablement un incrément prograde lors de l'augmentation des condi-tions P-T dans un contexte de mise en place de nappes. Le second groupe d'âges, vers 325-320 Ma correspond aux cris-taux de monazite ayant cristallisés à partir de liquides silicatés néoformés. Il est interprété comme l'âge de cristallisation des leucosomes des roches partiellement fondues suite à un événement régional de fusion partielle. Le dernier groupe d'âges, vers $320 \mathrm{Ma}$, correspondant aux domaines de bordure des cristaux de monazite des massifs de granite " tardifs ". Il est interprété comme l'âge de mise en place de la plupart des grands massifs granitiques et clos ainsi l'épisode de fusion partielle.

1. Université d'Orléans, ISTO, UMR 7327, 45071 Orléans, France

2. CNRS/INSU, ISTO, UMR 7327, 45071 Orléans, France

3. BRGM, ISTO, UMR 7327, BP 36009, 45060 Orléans, France

4. Université de Franche-Comté, UMR-CNRS 6249, Chrono-Environnement, 25030 Besançon, France 
L'introduction et la généralisation de la fusion partielle initiée dans les conditions du pic métamorphique coïncident donc avec un changement majeur du régime tectonique à l'échelle régionale. A la lumière de ces résultats, cela implique (1) soit que l'empilement d'unités crustales, riches en radioéléments a conduit à une augmentation de la température au sein du prisme orogénique provoquant la fusion partielle, la chute de résistance de la croûte entraînant alors l'effondrement et l'échappement latéral de la chaîne, (2) soit qu'un changement important des conditions aux limites ait induit la remontée d'asthénosphère chaude ayant conduit à l'apparition synchrone d'extension en surface et de fusion partielle en profondeur. A une échelle plus locale, la déformation semble avoir profité de la faible résistance des corps magmatiques avant leur cristallisation complète favorisant la localisation de la déformation dans les grands laccolithes du domaine Sud Armoricain souvent désignés comme des plutons syncinématiques.

\section{INTRODUCTION}

Partially molten rocks or migmatites are a common feature of mature orogens [i.e. Sawyer, 1994, 1999; Brown, 1994, 2001; Vanderhaeghe and Teyssier, 2001; Vanderhaeghe, 2004]. Together with strain rates and thermal conditions, partialmelting controls the rheological behaviour of crustal materials by drastically reducing the bulk strength of the crust [i.e. Arzi, 1978; Vigneresse et al., 1999; Rosenberg and Handy; 2005]. Along with a decrease of tectonic boundary forces, a decrease in the strength of a thickened crust is associated with gravitational collapse of an orogenic belt and the transition from crustal thickening to crustal thinning [i.e. Rey et al., 2001; Vanderhaeghe and Teyssier, 2001; Tirel et al., 2008; Rey et al., 2009a; 2009b]. Inception of partial-melting in the core of an orogenic belt may thus promote drastic changes in the balance of forces and thus represents a major turning-point in its evolution. Partial-melting in the thickened crust can either be an ulti-mate consequence of the stacking of radiogenic continental crustal slices or is due to a drastic change in heat supply from underneath as in the case of convective removal or slab retreat [England and Thompson, 1986; Houseman, 1988; Vanderhaeghe et al., 2003].

Besides, intrusion of magmas in higher structural levels or even in the upper brittle crust can locally promote strain localisation as shown by the formation of detachments at the roof of plutons [i.e. Daniel and Jolivet, 1995; Grasemann and Petrakakis, 2007; Jolivet et al., 2010] or even along volcanic sills or feeders [Famin and Michon, 2009]. The low strength of a magmatic body must have, at least temporarily, drastic consequences on strain localisation [Hutton, 1982; Neves et $a l ., 1996]$. It is thus crucial to recognise the timing of both the bulk loss of crustal strength during large-scale partial-melting events and localising events during magmatic intrusions at more local-scale. In both cases, accurate dating of

the crystallisation of melts either trapped at depth in migmatite complexes or after upward migration as plutons or dykes may put crucial age-constraints on important changes on mountain belts dynamics.

The case of the West-European segment of the Variscan belt is quite exemplary of this topic. Indeed, one of the most striking features of the belt is the abundance of both migmatitic and plutonic rocks, partly obliterating the initial architecture of the orogen. In the coastal South Armorican of typical "migmatite-cored metamorphic core complexes" [Brown, 2005; Turrillot et al., 2011a]. Moreover, most of the major shear zones are underlined by syntectonic granite laccoliths, strengthening the link between strain localiza-tion and presence of melt at the scale of the pluton [Gapais et al., 1993; Cagnard et al., 2004; Turrillot, 2010]. How-ever, to date, time-constraints are scarce and partly conflict-ing, hindering the understanding of this crucial stage in the Variscan belt evolution. This paper provides 29 new, and sometimes pioneer, $\mathrm{U}-\mathrm{Th} / \mathrm{Pb}$ chemical ages on monazite from the main occurrences of migmatites and regional clas-sic plutons exposed along the coast of the South Armorican domain. Together with an accurate separation of inheritance from neoformation, statistics on the dataset ensures internal consistency of the timeconstraints at regional-scale, shedding light on the dynamics of the late-orogenic stages of the West-European Variscanides.

\section{GEOLOGICAL SETTING}

The French Armorican massif (fig. 1) is one of the largest pieces of the Variscan belt that extends throughout western and central Europe [i.e. Matte, 1991, 2001]. Together with the Alleghanian belt, further to the West, the Variscan belt

resulted from the convergence of Laurussia and Gondwana that participated in the formation of the supercontinent Pangaea during the Late Paleozoic [e.g. Ballèvre, 2007; Ballèvre et al., 2009; Nance et al., 2010]. The structural pattern of the Armorican massif is currently dominated by Carboniferous W-E to NW-SE striking, dextral strike-slip faults, namely the North Armorican shear zone (NASZ), and the South Armorican shear zone (SASZ) (fig. 1B [e.g. Cogné, 1974; Watts and Williams, 1979; Jégouzo, 1980; Matte, 1986; Le Corre et al., 1991; Tartèse et al., 2011a]).

Furthermore, the SASZ is subdivided into an E-W, and a NW-SE striking northern and southern branches, respectively. From the paleogeographic point of view, the Armorican massif is divided into three main distinct parts, namely the Léon, North-Central, and South-Armorican domains bounded by major tectonic contacts whose importance is compared to suture zones: the Conquet-Penzé (LCPS), and Nort-sur-Erdre (NSES) sutures (fig. 1) [e.g. Cogné, 1974; Jégouzo, 1980; Le Corre et al., 1991; Jégouzo and Rossello, 1988; Cartier et al., 2001; Cartier and Faure, 2004; Gumiaux et al., 2004; Faure et al., 2005]. These domains drastically differ by their metamorphic grade and structural 
granites currently represent ca. $50 \%$ of the outcropping surface has long been described [e.g. Cogné, 1974]. Besides, a close association between crustal partial-melting, magmas and the development of extensional shear zones (i.e. detachments) has been recently reemphasised with the description style [e.g. Le Corre et al., 1991; Ballèvre et al., 2009; Faure et al., 2008a]. The North-Central Armorican domains experienced only moderate shortening and shearing between two main suture zones and mainly behaved as rigid, upper-crustal continental domains [i.e. Le Corre, 1977; Le 
Corre et al., 1991]. Conversely, the Léon and the South Armorican domains experienced a succession of tectonometamorphic events related to subduction, collision and finally gravitational collapse phases [Gapais et al., 1993; Ballèvre et al., 2009]. The South Armorican domain con-sists of two parts. Between the Nort-sur-Erdre eo-Variscan suture and the southern branch of the SASZ, the Ligerian domain is an area characterised by Early Paleozoic ophiolites, highpressure mafic and felsic rocks, and Devo-nian migmatites recently dated at ca. $387 \pm 8$ Ma (fig. 1) [Marchand, 1981; Ballèvre et al., 1994; Bosse et al., 2000; Cocherie et al., 2005; Faure et al., 2008b]. To the south of the southern branch of the SASZ, the coastal South Armori-can domain exhibits metamorphic and granitic rocks [Cogné, 1974; Berthé et al., 1979; Jégouzo, 1980].

In the following, only the geology of the coastal South Armorican domain is detailed (fig. 1a). Readers unfamiliar with the geology of the Armorican massif are referred to recent publications [Gumiaux et al., 2004; Faure et al., 2005, 2008b; Ballèvre et al., 2009]. Regionally, the coastal South Armorican domain can be divided in three main groups of units, from top to bottom (fig. 1b) [e.g., Cogné, 1949, 1974; Le Corre et al., 1991; Gapais et al., 1993; Cagnard et al., 2004; Turrillot et al., 2011a]:

1) the Upper units, formed by metamorphic rocks that have been equilibrated along a ca. $10^{\circ} \mathrm{C} / \mathrm{km}$ HP/LT subduction gradient. The uppermost units, exposed in the Bois de Céné and Ile de Groix klippes are made of chloritoidmicaschists, lawsonite-blueschists, garnet-blueschists and eclogites derived from metasediments, metabasites and rare felsic layers [Bosse et al., 2000; El Korh, 2010]. The pres-ence of both tholeiitic and alkaline signatures of the metabasites and Mn-rich metasediments argues for an initial oceanic setting or an intracontinental rift [Bernard-Griffiths et al., 1986; Audren and Plaine, 1986; Audren et al., 1997; El Korh et al., 2012]. Metamorphic peak-conditions reached around 18-20 kbar and $450-500^{\circ} \mathrm{C}$ [Bosse et al., 2002; Ballèvre et al., 2003] and were followed by a limited retro-gression into the greenschist facies conditions [Bosse et al., 2002]. The lower ones (i.e. Belle-Ile group) consist of mo-notonous series of metamorphosed volcanics intercalated with black-shales (i.e. the Vendée and Belle-Ile-en-Mer por-phyroids) and graphite-rich micaschists (i.e. Saint-Gilles micaschists). Age of the series was recently settled at ca. $480 \mathrm{Ma}$ in Vendée by dating the emplacement age of the por-phyroids [Ballèvre et al., 2012]. P-T estimates for the Belle-Ile group rocks yielded HP/LT metamorphic peakcon-ditions of $7-9 \mathrm{kbar}$ and $350-400^{\circ} \mathrm{C}$ [Le Hébel et al., 2002a];

2) the Intermediate units (i.e. the Vilaine Estuary and Sables d'Olonne units) made of metasediments in associa-tion with rare metavolcanics were equilibrated under a MP-MT gradient [Brown and Dallmeyer, 1996] while relics of HP/LT metamorphism have not been recognised. Meta-morphism increases downward from albite greenschist-facies to garnetstaurolite-biotite amphibolite-facies conditions [Bossière, 1988; Triboulet and Audren, 1988; Brown and Dallmeyer, 1996] and locally to partial-melting conditions to the southern Vendée [Goujou, 1992; Goujou et al., 1994]. Estimates of the metamorphic peak-conditions yielded 7-9 kbar for $620^{\circ} \mathrm{C}$ in the Vilaine Estuary area [Triboulet and Audren, 1985, 1988; Brown and Dallmeyer, 1996] and $9 \mathrm{kbar}$ for $650-700^{\circ} \mathrm{C}$ to the north of the Sables d'Olonne area, where localised partialmelting has been widely described [e.g. Ters, 1972; Brillanceau, 1978; Goujou, 1992; Cagnard et al., 2004]:

3) the Lower unit consists of high-grade rocks, migmatites and large volumes of granite recognised as the South Brittany Migmatite belt that extends to the south in Vendée [Marchildon and Brown, 2003]. Migmatites include restitic rocks with granulites, and kinzigites derived from preCarboniferous metasediments and Ordovician orthogneiss protoliths [Audren and Le Métour, 1976; Peucat et al., 1978, 1979; Brown, 1983; Peucat, 1983; Audren, 1987; Jones and Brown, 1990; Marchildon and Brown, 2003]. P-T estimates yielded metamorphic peak-conditions at 8-10 kbar and 750$800^{\circ} \mathrm{C}$ accompanied and followed by distinctive melt extraction stages down to $4 \mathrm{kbar}$ and $750^{\circ} \mathrm{C}$ [Brown, 1983; Jones and Brown, 1989, 1990; Jones, 1991; Goujou, 1992; Audren and Triboulet, 1993; Brown and Dallmeyer, 1996; Marchildon and Brown, 2003; Johnson and Brown, 2004].

Until now, the knowledge of the tectonic evolution of the coastal South Armorican domain remains incomplete. However, an overall two-stepped tectonometamorphic evolution of the domain can be drawn including an initial episode of subduction and crustal-thickening tectonics followed by pervasive extensional tectonics [Brun and Burg, 1982; Burg et al., 1987, 1994; Gapais et al., 1993]. Evidence for the subduction stages are quite well preserved in the upper units, particularly in the Ile de Groix and the Bois de Céné klippes where typical subduction-related blueschists and eclogites occur in different tectonics slices [e.g. Barrois, 1883; Carpenter, 1976; Quinquis et al., 1978; Bosse et al., 2002; Ballèvre et al., 2003]. Architecture of the Ile de Groix has even been interpreted as a remnant of a south-east-verging accretionary wedge related to a northward dip-ping subduction [Ballèvre et al., 2007]. Metamorphic phengite from HP assemblages yielded Late Devonian-Early Carboniferous $\mathrm{Rb} / \mathrm{Sr}$ and ${ }^{40} \mathrm{Ar} /{ }^{39} \mathrm{Ar}$ ages at 370-360 Ma, while retrogression and final cooling under greenschist-facies conditions occurred at around 355-345 Ma [Le Hébel, 2002; Bosse et al., 2005]. These uppermost units are systematically found at the top of the Variscan edifice, overthrusted on lower pressure continental units [Bosse et al., 2005]. Subsequent accretion of continental slices by thrusting in the orogenic wedge is also locally preserved as exemplified by the tectonic superimposition of the porphy-roids HP/LT units over low-grade metasediments in Vendée [Ters, 1972; Iglesias and Brun, 1976; Burg, 1981; Maillet, 1984; Colchen and Poncet, 1987; Vauchez et al., 1987; Goujou, 1992; Geoffroy, 1993]. While N-S directions and a preferred top-tothe South sense of shear were proposed [Cannat and Bouchez, 1986], kinematics of thrusting at a regional-scale remain currently not documented [Le Hébel, 2002]. Similarly, the age of final nappe-stacking is only lo-cally settled to the Tournaisian (i.e. 359-347 Ma) as re-corded by syn-thrusting sedimentation [Maillet, 1984; Colchen and Poncet, 1987; Rolin and Colchen, 2001].

The tectono-metamorphic record of the crustal thicken-ing stages were erased by pervasive partial-melting and extensional tectonics during a subsequent late-orogenic stage [Burg, 1981; Brun and Burg, 1982; Cannat and Bouchez, 1986; Gapais et al., 1993; Marchildon and Brown, 2003; Cagnard et al., 2004; Brown, 2005; Turrillot et al., 2009, 2011a]. During this stage, the Lower unit was exhumed as a series of domes locally referred to as 


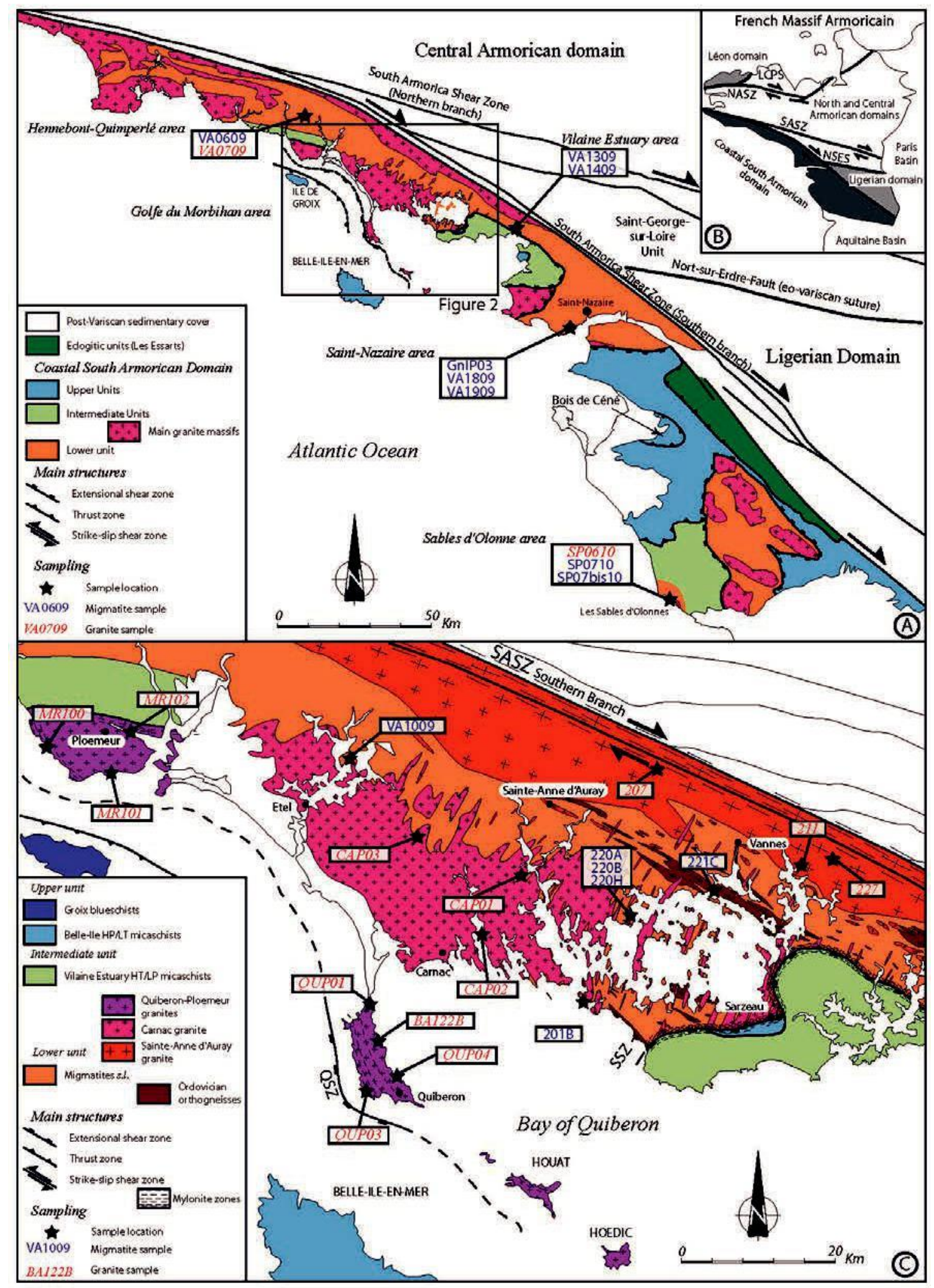

FIG. 1. - Geological maps of the studied area.

(a) Simplified geological map of the coastal South Armorican domain [modified after Gapais et al., 2009 and Bitri et al.,2010]. Indicated is the location of the samples used for $\mathrm{U}-\mathrm{Th} / \mathrm{Pb}$ chemical datings. (b) Inset is a sketch map of the French Armorican massif and its main subdivisions. The black rectangle is the location of Golfe du Morbihan area presented in figure 1c. (c) Simplified geological map of the Golfe du Morbihan area [Turrillot, 2010]. The location of samples that provided ages for Sainte-Anne d'Auray and Sarzeau granites is also indicated [Turrillot et al., 2009]. Only the units corresponding to the coastal South Armorican domain have been represented. Note the close association between the migmatite fabrics and the anatectic bodies and particularly the Sainte-Anne d'Auray anatectic granite massif. Conversely, the Carnac, Ploemeur and Quiberon granite intrusions clearly cut across the migmatite fa-brics and the Sainte-Anne d'Auray granite. These plutons locally emplaced within the upper units. 
migmatite-cored metamorphic core complexes [Brown, 2005; Turrillot et al., 2011a] surrounded by the overlying intermediate and Upper units (fig. 1) [Gapais et al., 1993; Burg et al., 1994; Le Hébel, 2002]. At regional-scale, defor-mation associated with the exhumation of the Lower Unit is marked by a regional flat-lying planar fabric, and a domi-nantly W-E to WNW-ESE striking stretching lineation with the exception of the Saint-Nazaire area where the stretching direction strikes almost ca. N-S [Bouchez et al., 1981; Gapais et al., 1993; Turrillot, 2010]. Besides, despite strik-ing structural similarities, two contrasted modes of crustal extension were opposed within the coastal South Armorican domain [Cagnard et al., 2004], and one can distinguish from southeast to northwest: 1) the southeastern end of the domain, in the Sables d'Olonne area, where extensional tec-tonics is mainly accommodated by pervasive vertical thin-ning of the entire metamorphic series [Iglesias and Brun, 1976; Goujou, 1992] and 2) the Golfe du Morbihan area and to some extent, the Saint-Nazaire area toward the north-west of the domain, where, conversely, most of extension appear concentrated along major extensional shear zones [e.g. Bouchez et al., 1981; Guillet et al., 1983; Gapais et al., 1993; Turrillot et al., 2009]. Strikingly, most of these extensional shear zones are marked by large tabular two-mica plutons emplaced during shearing within the base of overlying units [Vigneresse, 1978; Gapais et al., 1993; Gumiaux, 2004; Turrillot et al., 2011b]. Most of these plutons remain undated.

Initially attributed to a Proterozoic basement [Ters, 1979; Wyns and Le Métour, 1983], migmatites of the Inter-mediate and the Lower units yielded two age groups: a De-vonian group including ages at $376 \pm 19 \mathrm{Ma}$ and $372 \pm 24 \mathrm{Ma}$ in the Golfe du Morbihan area [Peucat, 1983] and at $388 \pm 8 \mathrm{Ma}$ in the Sables d'Olonne area [Vidal, 1980] by

whole-rock $\mathrm{Rb} / \mathrm{Sr}$, and zircon $\mathrm{U} / \mathrm{Pb}$ methods and a younger, ca. $320 \mathrm{Ma}$ age group (i.e. ${ }^{207} \mathrm{~Pb} /{ }^{206} \mathrm{~Pb} 323 \pm 4 \mathrm{Ma}$ and

$315 \pm 9 \mathrm{Ma}$ ages on monazite) [Peucat, 1983]. However, these Devonian ages were recently questioned in the Golfe du Morbihan area by monazite in situ $\mathrm{U}-\mathrm{Th} / \mathrm{Pb}$ chemical dating from a foliation-parallel granitic stock closely asso-ciated to the migmatites that yielded a $322 \pm 3$ Ma age [Turrillot et al., 2009]. This Late Carboniferous age com-plies with the clustering of many isotopic systems around ca. 315-300 Ma both in the Lower unit and the base of the Intermediate unit, suggesting a common final cooling [Carpena et al., 1979; Peucat, 1983; Goujou, 1992; Gapais et al., 1993; Brown and Dallmeyer, 1996; Turrillot et al., 2011a]. Besides, geochronological data of synkinematic crystallisations along the Quiberon and the Sarzeau extensional shear zones yielded similar 305-300 Ma ages [Brown and Dallmeyer, 1996; Ruffet in Le Hébel, 2002; Turrillot et al., 2011a; Tartèse et al., 2011b].

\section{SAMPLING, METHOD AND PROCEDURE}

\section{Sampling strategy and description of the outcrop conditions}

Fourteen samples of migmatite were collected from five zones distributed along the coastal South Armorican do-main (fig. 1a), namely, from the NW to the SE, the HennebontQuimperlé, the Golfe du Morbihan (fig. 1c), the Vilaine Estuary, the Saint-Nazaire and the Sables d'Olonne areas. Samples were all collected from outcrops showing unambiguous fabrics. Besides, samples sometimes carry evidence of weathering but are systematically devoid of macroscopic alteration. In order to avoid mixing between ageinheritance and melt-related crystallization ages, a par-ticular attention has been paid to separate the juvenile melt fractions, represented by leucosomes either parallel or dis-cordant to the foliation, from cumulative restites (i.e. melanosome) or from remnants of the initial gneiss (i.e. paleosome or mesosome) (fig. 2) [sensu Mehnert, 1968; Brown, 1973; Vanderhaeghe, 2009]. To gather independent age-constraints, this set of samples was completed by 15 granite samples. Among the collection, 5 samples corre-spond to the diffuse-boundary granites often referred to as "anatectic" granites, closely associated with the migmatites [Carron et al., 1994]. The 10 other samples correspond to "late", sharp-boundary granites cutting across the migmatite fabrics either at the scale of the map (fig. 1c) or the scale of the outcrop (fig. 2, 3, 4). A particular attention was paid on the Golfe du Morbihan area, which is, to date the most stud-ied segment of the coastal South Armorican domain as it of-fers different generations of intrusive rocks of contrasted chemistry and mineralogy (fig. 1c) [Augier et al., 2011]. Accordingly, a set of 19 samples was specifically picked from migmatites and different granite generations (i.e. 6 and 13 samples, respectively). Location of all samples is re-ported in figure 1.

\section{The Golfe du Morbihan area}

The Golfe du Morbihan area appears as the best exposed occurrence of migmatite of the Lower unit roofed by two major extensional shear zones characterised by opposite kinematics [e.g., Gapais et al., 1993; Turrillot et al., 2009]. In the core of the Lower unit, migmatites present a $\mathrm{N} 110-120^{\circ} \mathrm{E}$ striking subvertical foliation [Audren, 1987; Turrillot et al., 2009, 2011a; Augier et al., 2011]. Conversely, foliation adopts a gently dipping attitude in the vicinity of shear zones. There,

a conspicuous $\mathrm{N} 115^{\circ} \mathrm{E}$ stretching lineation is associated with non-coaxial kinematic indicators [e.g. Gapais et al., 1993; Turrillot et al., 2009]. Several generations of granite were distinguished including anatectic granite bodies that are diffuse within the migmatite and "late" granite plutons and dykes clearly cutting across the migmatite fabrics [e.g. Carron et al., 1994; Augier et al., 2011]. Anatectic granites occur in close association with migmatites as various scale bodies and develops North of Vannes as a $70 \mathrm{~km}$ long elon-gated massif, regionally known as the Sainte-Anne d'Auray magmatic complex [Cogné, 1974; Carron et al., 1994; Augier et al., 2011]. Among the "late" intrusive granites, the Carnac magmatic complex is composed of a main pluton and a pervasive dyke array [Carron et al., 1994; Augier et al., 2011]. Finally, to the southwest a series of two-mica leucogranite plutons including the Ploemeur, Quiberon and Houat-Hoedic plutons are emplaced within the Intermediate and the Upper units. Intensively sheared during their emplacement, these plutons may have trig-gered, at least locally, strain localisation [Gapais et al., 1993; Turrillot et al., 2009; Turrillot, 2010].

In the field, depending on the bulk protolith chemistry, on the mechanisms of melt extraction or on subtle differ-ences of peak-metamorphic conditions, migmatites display a wide range of textures and facies (e.g. compare fig. 3a to 
fig. 3b, fig. 3c and fig. 3d) [Brown, 1983; Audren, 1987; Jones and Brown, 1990; Audren and Triboulet, 1993; Brown and Dallmeyer, 1996; Marchildon and Brown, 2003]. How-ever, high-grade gneisses, metatexites, diatextites and anatectic granite stocks are unequally distributed and an overall northward increase in the amount of both the in situ melt and the melt collected from the center of the Golfe du Morbihan is classically described [i.e. Audren, 1987; Audren and Triboulet, 1993]. 19 samples were selected throughout the area. 6 samples of migmatite were picked from the northern part of the Ria d'Etel, to the west, to the southern part of Golfe du Morbihan, to the east (fig. 1c). Underlined by the alternation of quartzfeldspar irregular leucosomes and dark biotite (-sillimanitegarnet) melanosomes, the foli-ation is dominantly oriented $\mathrm{N} 110-130^{\circ} \mathrm{E}$ and locally isoclinally folded (fig. 3a). Samples 201, 220A and 220B were sampled from leucosome-rich metatexites (fig. 3b). Conversely, samples $220 \mathrm{H}$ and $221 \mathrm{C}$ were selected from bi-otite-sillimanite-garnet restitic layers (fig. 3c). In order to evaluate the effects of local inheritance on the U-Th/Pb system, samples 220A, 220B and 220H were selected on the same outcrop 10 centimetres apart (fig. 3b). Sample VA1009, located to the north of the Ria d'Etel, is a diatexite that presents a well-developed subhorizontal foliation and a conspicuous $\mathrm{N} 115^{\circ} \mathrm{E}$ stretching lineation (fig. 3d). To strengthen the probable genetic link between the migmatites and the anatectic massifs, 3 samples were collected in different petrographic facies throughout the Sainte-Anne d'Auray massif (i.e. samples 207, 211 and 227). Samples 207 and 211 were selected from a porphyritic biotite granite and coarsegrained granite facies (e.g. fig. 3e), while sam-ple 227 was selected from a two-mica fine-grained granite [Augier et al., 2011].

In addition, 13 samples are representative of the "late" intrusive granite massifs (fig. 1c). 3 samples were collected from the Carnac massif to illustrate the petrological vari-ability within the pluton from a biotite (-cordierite) facies (i.e. sample CAP01) to the west, to two-mica granite facies (i.e. samples CAP02 and CAP03). In the field, Carnac gran-ite dykes clearly cut across the migmatite fabrics and the Sainte-Anne d'Auray granite (figs 2 and 3f). 7 samples were collected from the Ploemeur and the Quiberon massifs (i.e. 3 and 4 samples, respectively). The dense sampling in the Ploemeur and the Quiberon two-mica leucogranites reflects the commitment to explore the possible effects of the mylonitic deformation and/or associated fluid circulations on the $\mathrm{U}-\mathrm{Th} / \mathrm{Pb}$ system in monazite. Sample BA122b, collected

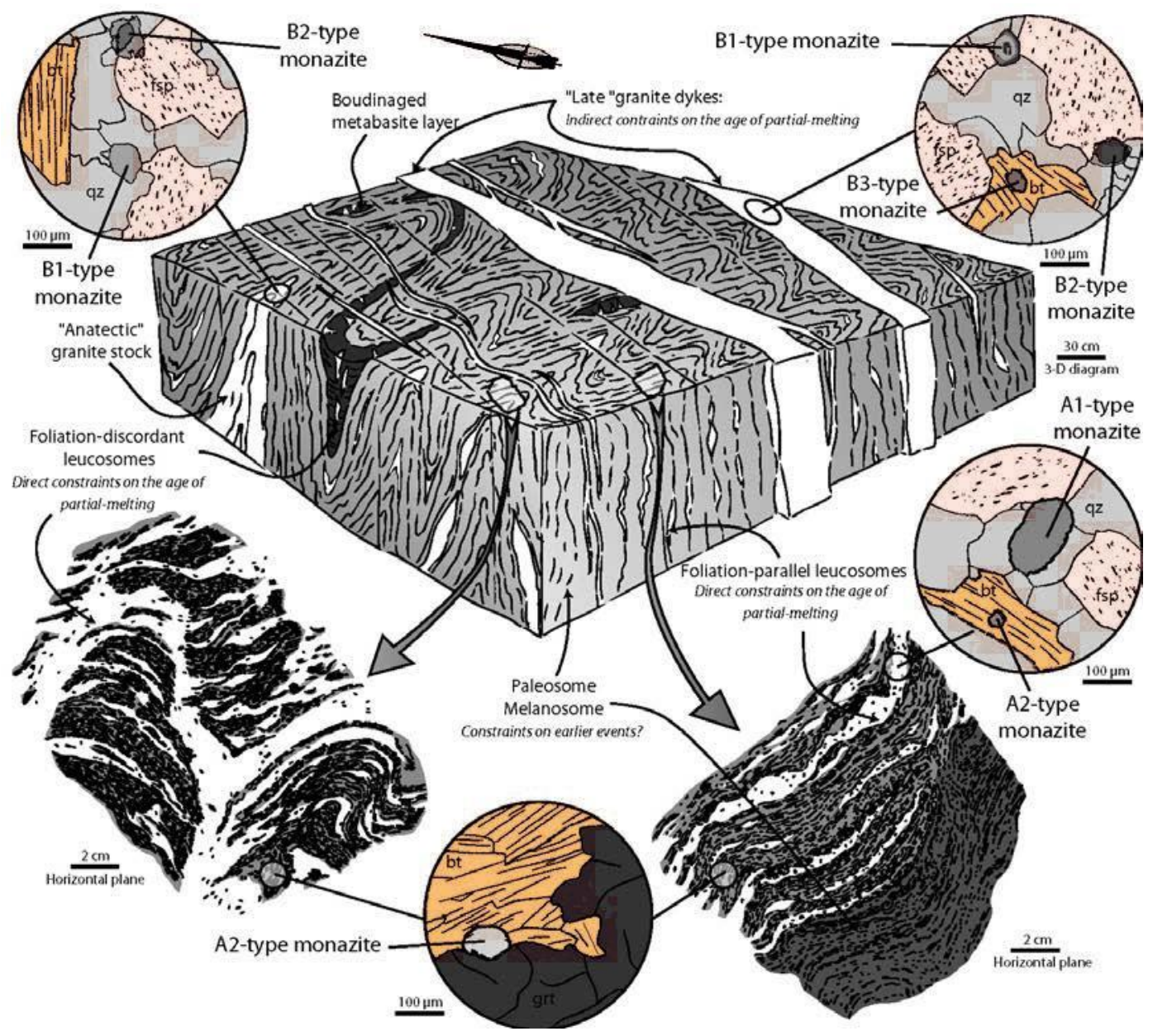

FIG. 2. - Sampling strategy scheme.

For each zone, melt-bearing migmatite samples were picked to gather the opportunity to sample newly-formed material and ultimately newly-formed mo-nazite grains. When possible, associated anatectic, generally foliation-parallel granite bodies were also sampled. Conversely, melanosome layers were col-lected to explore metamorphic record inheritance. Late to post-migmatite granite intrusions that remains poorly dated were also sampled to ensure an independent minimum age for the partial-melting event. Mineral abbreviations are after Whitney and Evans [2010]. 
in the eastern part, of the Quiberon peninsula is a weakly deformed granite sample. Samples MR100 and MR101 from the Ploemeur granite and samples QUP01 and QUP04 from the Quiberon granite are deformed granite samples (fig. $3 \mathrm{~g})$. Representative outcrops are characterised by heterogeneously developed planar-linear fabrics and locally

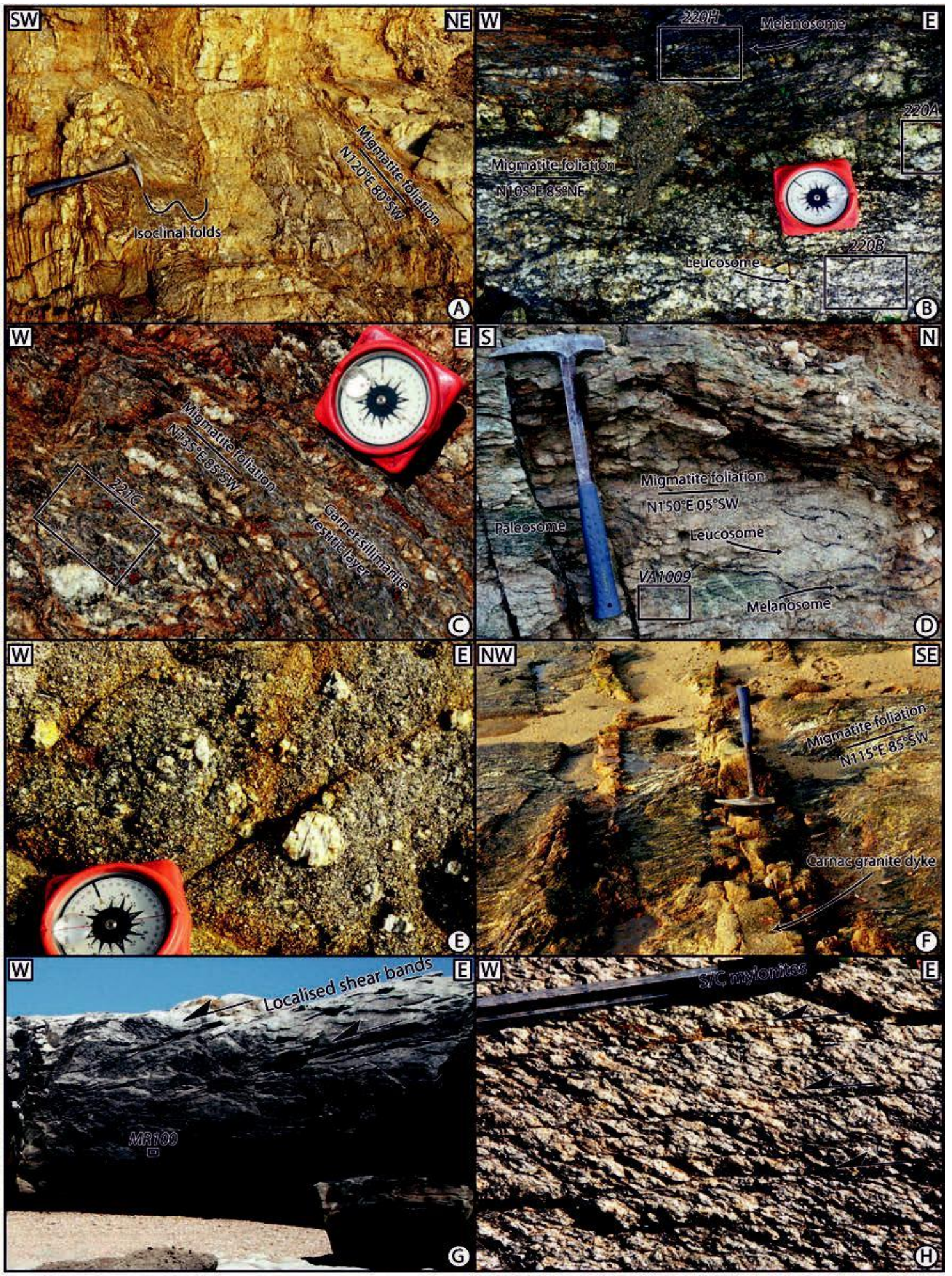

FIG. 3. - Representative pictures of the outcrop conditions of the migmatites and the granites in the Golfe du Morbihan area.

$(a, b$ and $c)$ Different outcrops of the Golfe du Morbihan showing the general aspects of the migmatites. Most outcrops are characterized by metatexites (a and $b$ ) while some consists in restitic layers (c). (d) Typical outcrop of the Etel area where migmatites present a subhorizontal attitude. (e) Detailed view of the heterogeneous porphyritic biotite granite facies of the Sainte-Anne d'Auray granite, few tens of meters north of the contact with the migmatites. (f) Cross-cutting relationships between the Carnac granite and the migmatites. Note that granite dykes clearly cut across the migmatite fabrics. (g) Deformed facies of the Ploemeur granite. Foliation is heterogeneously developed and most of the deformation concentrates along low-angle top-to-the-W extensional shear zones. (h) S/C mylonites developed at the expense of the Quiberon granite within the Quiberon extensional shear zone. 
displays evidence of meter-scale top-to-the-West shear zones (fig. 4g) [Turrillot, 2010]. Finally, sample MR102 from the Ploemeur granite and sample QUP03 from the Quiberon granite are typical S-C granite mylonites (fig. 4h) collected along the most deformed zones.

\section{The Hennebont-Quimperlé area}

The Hennebont-Quimperlé area is characterised by high-grade paragneisses and migmatites closely associated with anatectic granite bodies (fig. 1). Migmatites present $\mathrm{N} 110-120^{\circ} \mathrm{E}$ striking subvertical foliation [Cogné et al., 1986]. To the south, the migmatites present a rather gradual transition to the overlying micaschists units without evi-dence of important detachment zones [Cogné et al., 1986; Béchennec et al., 2012].

In the field, metatexites exhibit a rhythmic alternation of biotite ( sillimanite melanosomes and scarce well-developed quartz-feldspar leucosomes or small-scale anatectic granite stocks (fig. 4a). Laterally, the migmatites evolve to larger-scale lensoid stocks of anatectic granite bodies with 10-100 m typical dimension. Sample VA0609 was picked from a metatexite (fig. 4a). Sample VA0709 was sampled $5 \mathrm{~km}$ to the SE along the strike of the foliation from a ca. $2 \mathrm{~km}$ thick anatectic granite stock [Cogné et al., 1986; Béchennec et al., 2012].

\section{The Vilaine Estuary area}

The Vilaine Estuary area is characterised by a $2 \mathrm{~km}$ large band exposing migmatites, limited to the north by the Sainte-Anne d'Auray anatectic granite through a diffuse transition [Plaine et al., 1984]. To the south, the migmatites are separated from the Intermediate units by a ca. 100-150 m thick gently-dipping mylonite zone belonging to the Sarzeau extensional shear zone [Plaine et al., 1984; Turrillot et al., 2009, 2011a; Augier et al., 2011]. While the $\mathrm{N} 120^{\circ} \mathrm{E}$ strike of foliation remains consistent regionally, the dip of the metamorphic layers evolves from subvertical in the vicinity of the Sainte-Anne d'Auray granite to gentle $\left(20-40^{\circ}\right)$ toward the south and the Sarzeau shear zone [Plaine et al., 1984; Augier et al., 2011].

At the outcrop-scale, most rocks present conspicuous evidence of partial-melting and the increase in the amount of the in situ melt toward the north, where a ca. $500 \mathrm{~m}$ large diffuse zone marks the southern boundary of the Sainte-Anne d'Auray granite massif (fig. 1) [Plaine et al., 1984]. Two samples, (VA1309 and VA1409) were picked from leucosomerich metatexites at ca. 500-700 $\mathrm{m}$ to the south of the SainteAnne d'Auray granite massif (fig. 4b).

\section{The Saint-Nazaire area}

The Saint-Nazaire area appears as a large outcrop of the Lower unit (fig. 1). The overall structure of the Lower unit defines a structural dome, namely the St-Nazaire dome [Cogné, 1974], with a dominant gently north-dipping folia-tion to the northwest (i.e. La Baule area) and a gently south-dipping foliation to the south (i.e. Saint Brévin area) [Ters et al., 1978; Ters, 1979]. On both flanks, the foliation bears a N-S striking lineation [Bouchez et al., 1981; Guillet et al., 1983]. To the south, the dome is roofed by an extensional shear zone [e.g. Gapais et al., 1993; Turrillot, 2010; Bitri et al., 2010]. To the north, the contact with the
Intermediate unit is underlined by a large-scale syn-kine-matic gently north-dipping laccolith called the Guérande pluton [Vigneresse et al., 1978; Guillet et al., 1983]).

In the field (mostly along the coast), the migmatites consist of coarse-grained alternations of quartz and feldspar or even pegmatitic layers and of dark biotite, sillimanite and garnet layers. Locally, diatexites and anatectic granite stocks crop out in alternation with massive restitic layers or boudins embedded in a heterogeneous granite (fig. 4c). Sample GnIP03 corresponds to a migmatitic gneiss. Sample VA1909 was collected from a large leucosome stock within typical metatexites (fig. 4d), while sample VA1809 was sampled from a large restitic body (fig. 4e).

\section{The Sables d'Olonne area}

The regional-classic coastal section of the Sables d'Olonne area shows a complete Barrovian metamorphic sequence, from low-grade metasediments to the north, to migmatites to the south in the Sable d'Olonne bay [Ters, 1972; Iglesias and Brun, 1976; Goujou, 1992; Goujou et al., 1994] without evi-dence of major detachment zones [Cagnard et al., 2004]. E-W-striking and N-dipping in the northern part of the area, and WNW-ESEstriking and NE-dipping in the eastern part (fig. 4f), the overall attitude of the foliation is consistent with the dome-shaped structure [Goujou, 1992]. Along with meta-morphic grade, the intensity of the foliation strongly in-creases toward the north [Goujou, 1992; Goujou et al., 1994; Rolin and Colchen, 2001]. The foliation carries a clear E-W to WNW-ESE striking stretching lineation [Iglesias and Brun, 1976], while a dominant top-to-the-west sense of shear is observed [Brun and Burg, 1982; Cannat and Bouchez, 1986; Goujou, 1992; Cagnard et al., 2004; Turrillot, 2010].

In the field, conspicuous traces of partial-melting are only restricted to the southernmost parts of the section (fig. 1a). There, the N-dipping foliation is locally outlined by $\mathrm{cm}$ to $\mathrm{dm}$ sized leucosomes. A dense array of variably deformed dykes cuts across the migmatite fabrics (figs. $4 \mathrm{f}$ and $4 \mathrm{~g}$ ). Most of the dykes display conspicuous internal (i.e. foliation and lineation) or external strain (e.g. folds, boudins; fig. $4 \mathrm{~g}$ ) consistent with the strain axes defined from the migmatites [Cagnard et al., 2004]. Interestingly, some leucosome layers appear connected to the dykes indi-cating a clear synkinematic melt extraction. Samples SP0710 and SP07bis10 were sampled few meters apart from leucosome-poor metatexites of probably contrasted meta-sedimentary protoliths. Rich in biotite and sillimanite, sam-ple SP0710 rather corresponds to a metapelitic protolith while SP07bis10, rich in quartz to an impure mica-rich metaquartzite. Conversely, sample SP0610 was sampled within a granite dyke transposed in the regional foliation (fig. $4 \mathrm{~g}$ ).

\section{Sample preparation, analytical procedure and data processing}

Depending on the nature of the rock, preparation followed two different strategies. Because of the intrinsic complexity of migmatite in which neocrystallisation and inheritance are common, migmatite samples were studied on polished thinsections to perform in situ chemical datings on monazite (fig. 2). In situ analysis allows for combining geo-chronology and rock-texture (i.e. phases equilibria and ulti-mately P-T conditions) to make inferences on the crystallization conditions of monazite [e.g. Pyle and Spear, 
2003; Goncalves et al., 2004], particularly relevant for dating metamorphic rocks and migmatites. To ensure an accurate textural control, thin sections were cut in the $\mathrm{XZ}$ structural plane. Conversely, granites were mostly studied by mineral separation that provides the largest monazite grains likely to contain useful internal information on the

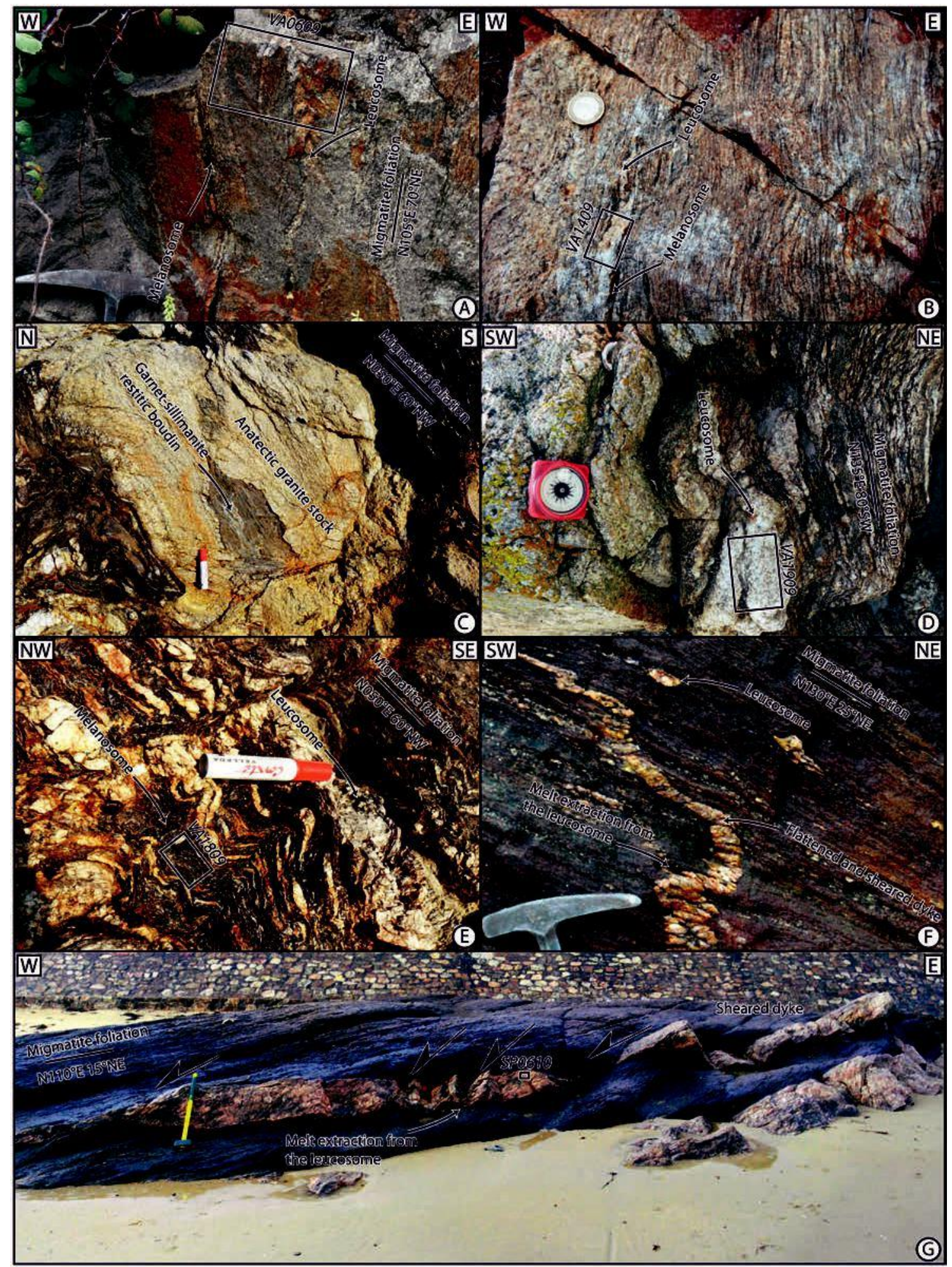

FIG. 4. - Representative pictures of the outcrop conditions of the migmatites and the granites in the other sampling areas.

(a) Interlayering of paleosome and finely alternating leucosome and melanosome in the Hennebont-Quimperlé area. (b) Leucosome-rich migmatites expo-sed in the Vilaine Estuary area. Note that the paleosome is still locally preserved. (c, $d$ and e) Representative pictures of the migmatites exposed on the coastal outcrop on the Saint Nazaire area. Picture (c) and (d) present different sizes of melt accumulation as foliation-concordant large leucosome (c) or as genuine small-scale anatectic granite stock (d). (f and g) General aspects of the migmatites and the granite dyke array in the Sable d'Olonne area. Note that leucosomes appear sometimes connected to the dykes indicating that melt extraction is synkinematic. 
growth and dissolution history of the grains [i.e. Kelsey et al., 2008]. Rocks were first finely crushed using disk grind-ers. Obtained powders were sieved and only the fraction size below $0.5 \mathrm{~mm}$ was retained. Then, mineral density sep-aration using heavy liquids, followed by magnetic separa-tion using a Frantz separator were applied to sort the monazite from other accessory heavy minerals. A final opti-cal control based on the morphological characteristics of phosphates was made. The separated monazite grains were hand-picked and mounted in epoxy as plots, with further fine polishing. Mineral separation has been made at BRGM (French Geological Survey). Reader unfamiliar with the de-tailed procedure is referred to recent publications [Be Mezeme, 2005; Turrillot et al., 2009].

The same analytical procedure was applied to all sam-ples. Monazite grains have been observed under JSM-6400 JEOL Scanning Electron Microscope (SEM) hosted at Institut des Sciences de la Terre d'Orléans (ISTO). Thin sections and polished plots were first coated by a thin car-bon layer. Acceleration voltage and beam-current intensity were $20 \mathrm{kV}$ and $10 \mathrm{nA}$, respectively. For thin-sections, SEM observations provided for the distinction of monazite from other accessory minerals, using Energy-Dispersive X-ray spectrometer (EDS) and IdFix Software package for data processing. Then, backscattered electrons (BSE) im-aging mode was used for evaluating intra-grain composition variations within monazite, whereas the textures were ex-amined with secondary electrons (SE) imaging mode. Only BSE images are here presented. Monazite grains were fur-ther analysed with the Cameca SX50 electron probe mi-cro-analyser (EPMA) cooperated by BRGM and ISTO, equipped with four Wavelength Dispersion Spectrometers (WDS). For this study, we have followed the procedure de-scribed by Cocherie et al. [1998]. The accelerating-voltage and beam-current intensity conditions were routinely fixed to $20 \mathrm{kV}$ and $100 \mathrm{nA}$ providing absolute error of $150 \mathrm{ppm}$ for $\mathrm{U}, \mathrm{Th}$ and $\mathrm{Pb}$ [Cocherie and Albarède, 2001]. Beam cur-rent intensity was increased to $200 \mathrm{nA}$, for samples SP0710 and SP07bis10, providing lower absolute errors for $\mathrm{U}$, Th and $\mathrm{Pb}$ of $105 \mathrm{ppm}, 130 \mathrm{ppm}$ and $110 \mathrm{ppm}$, respectively. As the respective amount of $U$ and Th may significantly vary in natural monazite [Linthout, 2007], relative errors for $\mathrm{U}$, Th and $\mathrm{Pb}$ can be very low especially when large amount of $\mathrm{U}$ and $\mathrm{Th}$ are incorporated in the monazite structure, and this may hide the errors due to instrumentation and background measurements. Therefore a minimum value of $2 \%$ is as-sumed for the relative errors. Natural and synthetic silicates, phosphates, oxides, and sulfides were used as standards. Total duration of background and peak counts is $240 \mathrm{~s}$ for $\mathrm{Pb}$, $200 \mathrm{~s}$ for $\mathrm{U}$, and $40 \mathrm{~s}$ for other elements (Ca, Ce, Gd, La, Nd, P, $\mathrm{Pr}, \mathrm{Si}, \mathrm{Sm}, \mathrm{Th}, \mathrm{Y})$. The EPMA resolution of $2 \mu \mathrm{m}$, combined with the high-resolution SEM images al-lows for avoiding the altered domains of the grains with possible significant $\mathrm{Pb}$ loss.

Structural formulae of monazite $(\mathrm{A} 4 \mathrm{~B} 4 \mathrm{O} 16)$ were also calculated to reveal the composition variations due to chemical substitutions between and within samples. Raw or treated data and chemical tables that can-not be presented here for space limitations are available upon request from the first author. Only the substitution be-tween monazite and cheralite $\left(\mathrm{Lnl}^{3+}+\right.$ $\mathrm{Si}^{4+} \leftrightarrow \mathrm{Ca}^{2+}+\mathrm{P}^{5+}$ ) is presented here.

Data sorting was further performed using the "EPMA dating” Excel ${ }^{\circledR}$ package [Pommier et al., 2002], to calculate individual $\mathrm{U}-\mathrm{Th}-\mathrm{Pb}$ age. Several filters $(15 \%<\mathrm{Ce}<35 \% ; 9 \%$ $<\mathrm{P}<17 \% ; \mathrm{Pb}>0,015 \% ; 97 \%<$ Total 103\%) were then applied to reject anomalous punctual results. Using ISOPLOT Excel(r) package [Ludwig, 2003], the mean age of each data population was calculated according to two methods:

- weighted average (mean) age calculation based on the regression line that intercepts the individual ages, which are weighted by the inverse of their related error. The aberrant values are thus easily rejected and the scattering of individ-ual ages with respect to the average age can be evaluated by calculating the Mean Square Weighted Deviation (MSWD);

- isochron $\mathrm{U}-\mathrm{Th} / \mathrm{Pb}$ age following the procedure of Cocherie and Albarède [2001]. As monazite may present a strong variability of the $\mathrm{Th} / \mathrm{U}$ ratio, $\mathrm{Th} / \mathrm{Pb}$ versus $\mathrm{U} / \mathrm{Pb}$ plots can be used to represent the individual data and their respective error (represented by ellipse of confidence). The isochron $\mathrm{U}-\mathrm{Th} / \mathrm{Pb}$ age of the sample was computed from different graphical parameters such as the slope with error of the best-fit line, the value of the $\mathrm{Th} / \mathrm{Pb}$ and $\mathrm{U} / \mathrm{Pb}$ inter-cept ages, and the coordinates of the centroid of the best-fit line.

\section{RESULTS}

All U-Th-Pb age-results calculated either as isochron $\mathrm{U}-\mathrm{Th} / \mathrm{Pb}$ age or as weighted average age, are presented in figures 5 to 10. A representative BSE image of the internal texture of monazite is given for each sample. For the sake of clarity, results are displayed according to sampling zones discriminated in figure 1.

\section{The Golfe du Morbihan area}

\section{Migmatite samples}

Sample VA1009, collected in the Ria d'Etel (western part of the Golfe du Morbihan) contains monazites of typical size below $50 \mu \mathrm{m}$. Monazite occurs as numerous sub-euhedral grains (fig. 5a) at the boundary between quartz and feldspar and frequently presents patchy zoning due to sectorial variations of $U$ and $T h$ contents. Individual data are scattered along a line in the $\mathrm{Th} / \mathrm{Pb}$ versus $\mathrm{U} / \mathrm{Pb}$ plot and a robust best-fit line can be drawn. The theoretical isochron is not strictly parallel to the best-fit line but both are similar within error and an U$\mathrm{Th} / \mathrm{Pb}$ isochron age at $325 \pm 6 \mathrm{Ma}$ has been calculated (fig. $5 \mathrm{a}$ ).

Sample 201B contains sub-rounded monazite grains of small size (below $50 \mu \mathrm{m}$ ) set at the boundary between quartz and feldspar or as inclusions in biotite. No compositional zoning has been observed by SEM imaging and the narrow range of $\mathrm{Th} / \mathrm{Pb}$ and $\mathrm{U} / \mathrm{Pb}$ ratios do not provide a well-constrained best-fit line. Nevertheless, the best-fit line is simi-lar within error to the theoretical isochron and an isochron $\mathrm{U}$ $\mathrm{Th} / \mathrm{Pb}$ age at $326 \pm 5 \mathrm{Ma}$ was calculated for this migmatite leucosome (fig. 5b).

Samples 220A, 220B and 220H, collected from the same outcrop include monazite of size ranging from $40 \mu \mathrm{m}$ to 100 $\mu \mathrm{m}$. In the leucosome (samples 220A and 220B), monazite occurs as sub-euhedral grains at the boundary be-tween quartz and feldspar and rarely as inclusion within bi-otite. Conversely, in the melanosome (sample $220 \mathrm{H}$ ), 
monazite occurs as slightly corroded euhedral grains enclosed in biotite or garnet. In these samples, no textural and chemical zoning has been observed or measured. For sample 220A, the best-fit line presents a large error envelop due to close values of the $\mathrm{Th} / \mathrm{Pb}$ and $\mathrm{U} / \mathrm{Pb}$ ratios. But the best-fit line is similar within error to the theoretical isochron, providing an isochron $\mathrm{U}-\mathrm{Th} / \mathrm{Pb}$ age at $323 \pm 6 \mathrm{Ma}$ (fig. 5c). For sample $220 \mathrm{~B}$, the wide range of $\mathrm{Th} / \mathrm{Pb}$ and $\mathrm{U} / \mathrm{Pb}$ ratios gives a good constraint for the best-fit line, which coincides within error with the theoretical isochron to yield an isochron $\mathrm{U}-\mathrm{Th} / \mathrm{Pb}$ age at $320 \pm 5 \mathrm{Ma}$ for this leucosome (fig. 5d). For sample $220 \mathrm{H}$, the values of the $\mathrm{Th} / \mathrm{Pb}$ and

$\mathrm{U} / \mathrm{Pb}$ ratios slightly vary and the best-fit line displays a large error envelope that incorporates the theoretical

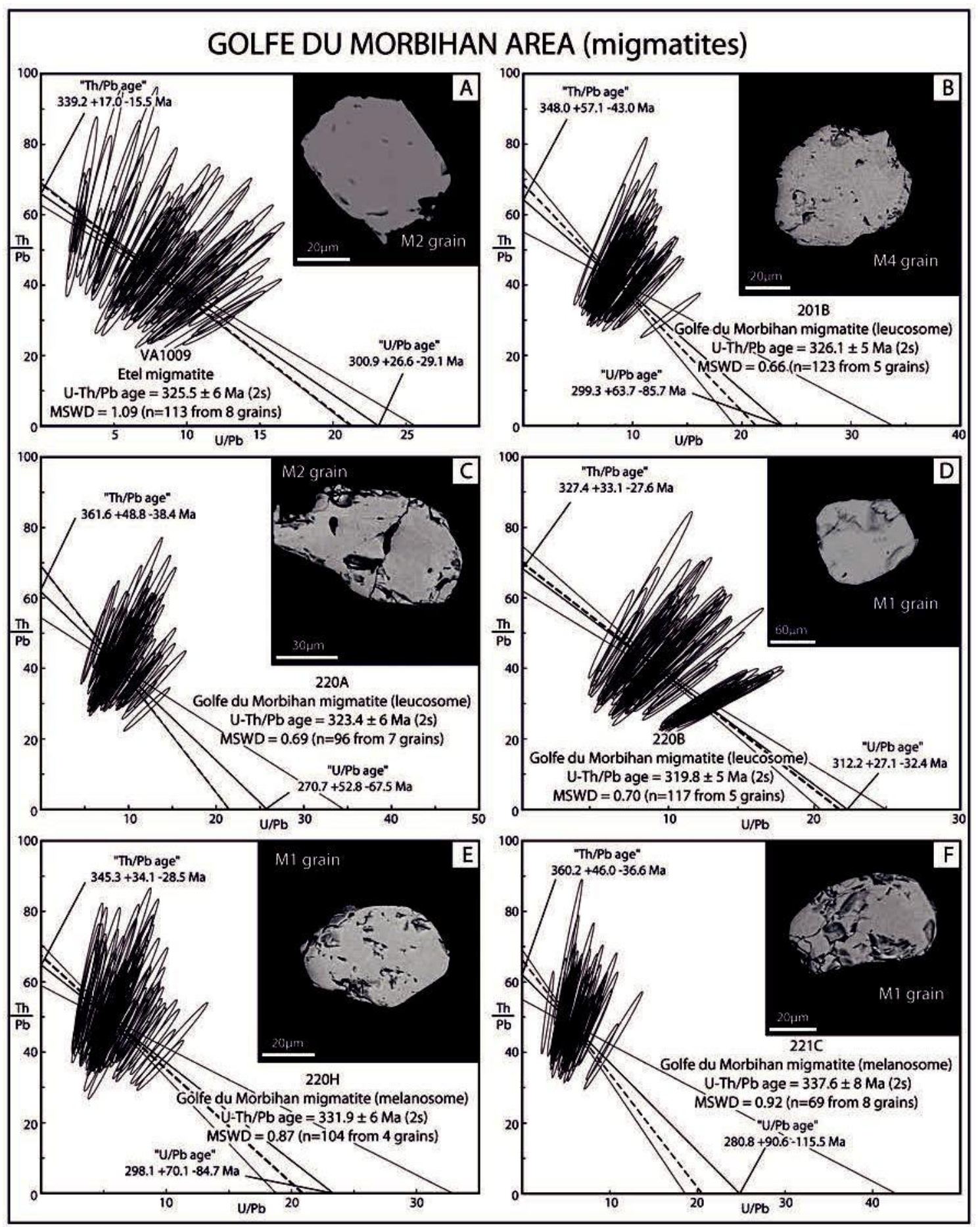

FIG. 5. - Geochronological results from migmatite samples collected in the Golfe du Morbihan area. For Th/Pb vs. U/Pb isochron diagrams, all standard deviations are quoted at $95 \%$ confidence level and error ellipses are plotted at 2 . Thick (thin) solid line corresponds to best-fit line (envelop error); dotted line is the theoretical isochron for the calculated isochron age and should be comprised in the error envelope. SEM images were obtained using back-scat-tered electrons (BSE) imaging mode. Chemical transect presents the spatial variations of $\mathrm{Ca}+\mathrm{P}$ and $\mathrm{LnL}+\mathrm{Si}$, according to monazite-cheralite substitu-tion. To illustrate internal composition zoning, average $\mathrm{UO}_{2}$ and $\mathrm{ThO}_{2}$ contents are also presented for each grain domain. Mineral abbreviations are after Whitney and Evans [2010]. T refers to as transects across monazite grains. 
isochron. The isochron $\mathrm{U}-\mathrm{Th} / \mathrm{Pb}$ age at $332 \pm 6 \mathrm{Ma}$ has been calculated for the melanosome (fig. 5e).

Sample 221C (melanosome) contains small monazite grains ranging from $20 \mu \mathrm{m}$ to $50 \mu \mathrm{m}$. The grains are subrounded and occur as inclusions in the biotite and in the garnet. SEM imaging does not reveal significant compositional zoning. The narrow range of $\mathrm{Th} / \mathrm{Pb}$ and $\mathrm{U} / \mathrm{Pb}$ ratios do not provide a well-constrained best-fit line, but the error enve-lope includes the theoretical isochron. The isochron $\mathrm{U}-\mathrm{Th} / \mathrm{Pb}$ age at $338 \pm 8$ Ma has been calculated (fig. 5f).

\section{Anatectic granite samples (Sainte-Anne d'Auray massif)}

Sample 207 contains very large sub-euhedral crystals of monazite (up to $200 \mu \mathrm{m}$ ) set at the boundary between quartz and feldspar or enclosed in biotite. Due to variable $\mathrm{U}$ and $\mathrm{Th}$ contents, a slight compositional zoning was observed (fig. 6a) and a darker core may be distinguished from a lighter rim. This mantle-core texture was additionally re-vealed by high-Ca and $\mathrm{P}$ content in the rim and high-REE, $\mathrm{Y}$ and $\mathrm{Si}$ content in the core (fig. 6b). However, for the anal-yses from the grain core, the range of $\mathrm{Th} / \mathrm{Pb}$ and $\mathrm{U} / \mathrm{Pb}$ ratios is very narrow; this leads to extremely large error envelope for the best fit line and high value of MSDW above validity criteria [Wendt and Carl, 1991]. The $\mathrm{Th} / \mathrm{Pb}$ versus $\mathrm{U} / \mathrm{Pb}$ plots cannot be drawn and no isochron $\mathrm{U}-\mathrm{Th} / \mathrm{Pb}$ age has been calculated for this sample. Weighted average (or Mean) ages have been determined instead, yielding ages of $318 \pm 3 \mathrm{Ma}$ and $327 \pm 9 \mathrm{Ma}$ for the rim and the core, re-spectively (figs. $6 \mathrm{c}$ and $6 \mathrm{~d}$ ).

Sample 211 also presents very large monazite grains (up to $200 \mu \mathrm{m}$ ), which are associated with zircon and apa-tite. Grains are euhedral (fig. 6e) or rounded and they do not present any internal variation of composition. The $\mathrm{Th} / \mathrm{Pb}$ and $\mathrm{U} / \mathrm{Pb}$ ratios strongly vary and give a robust con-straint to the best-fit line that is parallel to the theoretical isochron. An isochron $\mathrm{U}-\mathrm{Th} / \mathrm{Pb}$ age at $317 \pm 6 \mathrm{Ma}$ was thus calculated (fig. $6 \mathrm{e}$ ).

Sample 227 contains large sub-euhedral crystals of monazite (ca. $100 \mu \mathrm{m}$ ) set at the boundary between quartz, feldspar and biotite or enclosed in biotite. SEM imaging does not reveal any particular internal texture of the grains, as they present homogeneous content in $\mathrm{U}$ and $\mathrm{Th}$ (fig. 6f). However, based on other elements incorporated in the monazite composition, a rim rich in $\mathrm{Ca}$ and $\mathrm{P}$ can be distin-guished from a core rich in REE, Y and $\mathrm{Si}$ (fig. $6 \mathrm{~g}$ ). The in-dividual analyses that correspond to the rim present weak variations of the $\mathrm{Th} / \mathrm{Pb}$ and $\mathrm{U} / \mathrm{Pb}$ ratios, inducing a signifi-cant error for the best-fit line. This latter one is similar within error to the theoretical isochron, though, yielding an isochron $\mathrm{U}-\mathrm{Th} / \mathrm{Pb}$ age at $317 \pm 3$ $\mathrm{Ma}$ (fig. 6h). Conversely, individual data from the core well constrain the best-fit line that parallels the theoretical isochron and an isochron $\mathrm{U}-\mathrm{Th} / \mathrm{Pb}$ age at $335 \pm 6 \mathrm{Ma}$ has been calculated (fig. 6i).

\section{Carnac massif samples}

Sample CAP01 contains monazite, whose size ranges be-tween $50 \mu \mathrm{m}$ and $200 \mu \mathrm{m}$. The grains are often euhedral and SEM observation has revealed various types of inter-nal zoning, such as patchy zoning, mantle-core zoning or combination of both (fig. 7a). Zoning is caused by signifi-cant variations of the $U$ and Th contents in the monazite.
Variations of the other elements are also observed and two populations, namely a core and a rim can be distinguished. The two calculated isochron $\mathrm{U}-\mathrm{Th} / \mathrm{Pb}$ ages are similar within error $(320 \pm 4 \mathrm{Ma}$ for the rim and $323 \pm 6 \mathrm{Ma}$ for the core) and an average isochron $\mathrm{U}-\mathrm{Th} / \mathrm{Pb}$ age has been com-puted. The $\mathrm{Th} / \mathrm{Pb}$ and $\mathrm{U} / \mathrm{Pb}$ ratios are well distributed in the diagram providing very good constraints for the best-fit line that parallels the theoretical isochron. Hence, an isochron $\mathrm{U}-\mathrm{Th} / \mathrm{Pb}$ age at $321 \pm$ 3 Ma was calculated (fig. 7a).

Sample CAP02 presents very large euhedral monazite grains (up to $300 \mu \mathrm{m}$ ) showing growth and patchy zoning. This is due to differences of the $U$ and Th contents, and variations of other elements are also observed. Neverthe-less, it is difficult to discriminate two populations, as ob-served growth zoning reveals successive chemical stages during crystallization. Despite significant variations of the $U$ and Th contents, the range of the $\mathrm{Th} / \mathrm{Pb}$ and $\mathrm{U} / \mathrm{Pb}$ ratios is narrow and individual data are grouped, providing poor constraints for the best-fit line. This latter one is similar to the theoretical isochron, though, yielding an isochron $\mathrm{U}-\mathrm{Th} / \mathrm{Pb}$ age at $319 \pm 5 \mathrm{Ma}$ (fig. 7b).

In sample CAP03, small to medium-sized (below $100 \mu \mathrm{m}$ ) euhedral grains of monazite do not display evi-dence of zoning. The large variations of the $\mathrm{Th} / \mathrm{Pb}$ and $\mathrm{U} / \mathrm{Pb}$ ratios give robust constraints for the best-fit line that paral-lels the theoretical isochron. An isochron $\mathrm{U}-\mathrm{Th} / \mathrm{Pb}$ age has been calculated at 323 $\pm 5 \mathrm{Ma}$ (fig. 7c).

\section{Ploemeur-Quiberon leucogranite samples}

Sample MR100 from the Ploemeur massif contains me-diumsized $(80 \mu \mathrm{m}$ to $150 \mu \mathrm{m})$, generally sub-euhedral monazite grains that do not present evidence of zoning. The range of the $\mathrm{Th} / \mathrm{Pb}$ and $\mathrm{U} / \mathrm{Pb}$ ratios is wide and well con-strains the best-fit line, which parallels the theoretical isochron. An isochron U$\mathrm{Th} / \mathrm{Pb}$ age at $335 \pm 6 \mathrm{Ma}$ has been calculated for sample MR100 (fig. 7d). Sample MR101, presents medium size (80 $\mu \mathrm{m}$ to $150 \mu \mathrm{m})$ sub-rounded monazite grains. SEM observations did not reveal internal zoning (fig. 7e). Although there are no significant varia-tions of the $U$ and $T h$ contents, the composition of the monazite is heterogeneous. A horseshoe-shaped core with low $\mathrm{Ca}$ and $\mathrm{P}$ contents and high REE, Y and Si contents can be distinguished from a rim with high $\mathrm{Ca}$ and $\mathrm{P}$ contents and low REE, $\mathrm{Y}$ and Si contents (fig. 7f). Hence two diachronous populations have been distinguished. For the rim, the distribution of the $T h / P b$ and $\mathrm{U} / \mathrm{Pb}$ ratios provides a good constrain for the best-fit line and its error envelope that encompasses the theoretical isochron. Analyses from the rim yielded an isochron $\mathrm{U}-\mathrm{Th} / \mathrm{Pb}$ age at 320 $\pm 8 \mathrm{Ma}$ (fig. $7 \mathrm{~g}$ ). For the core, although the $\mathrm{Th} / \mathrm{Pb}$ and $\mathrm{U} / \mathrm{Pb}$ ratios are distributed in two separate groups, the best-fit line is similar within error to the theoretical isochron, yielding an isochron $\mathrm{U}-\mathrm{Th} / \mathrm{Pb}$ age at $333 \pm 8 \mathrm{Ma}$ (fig. $7 \mathrm{~h}$ ). Sample MR102 presents large, up to $200 \mu \mathrm{m}$ euhedral monazite grains. They do not present significant element variations within grains, and no internal texture has been observed un-der SEM. Despite a distribution of the $\mathrm{Th} / \mathrm{Pb}$ and $\mathrm{U} / \mathrm{Pb}$ ra-tios into two separate groups, the best-fit line presents a narrow error envelope and parallels the theoretical isochron. An isochron $\mathrm{U}-\mathrm{Th} / \mathrm{Pb}$ age at $316 \pm 4$ Ma has been calculated for sample MR102 (fig. 7i). 
Sample BA122b from the Quiberon massif contains medium-sized ( $30 \mu \mathrm{m}$ to $80 \mu \mathrm{m})$ sub-euhedral monazite grains, set between quartz and feldspar. The grains do not display any textural or compositional zoning, but the range of the $\mathrm{Th} / \mathrm{Pb}$ and $\mathrm{U} / \mathrm{Pb}$ ratios is wide, constraining the position of the best-fit line accurately. This latter one is parallel to the theoretical isochron, and an isochron $\mathrm{U}-\mathrm{Th} / \mathrm{Pb}$ age at $320 \pm 3$ Ma has been calculated for sample BA122b (fig. 8a). Sample QUP01 generally presents large (up to $300 \mu \mathrm{m}$ ) euhedral monazite grains. SEM observations have revealed

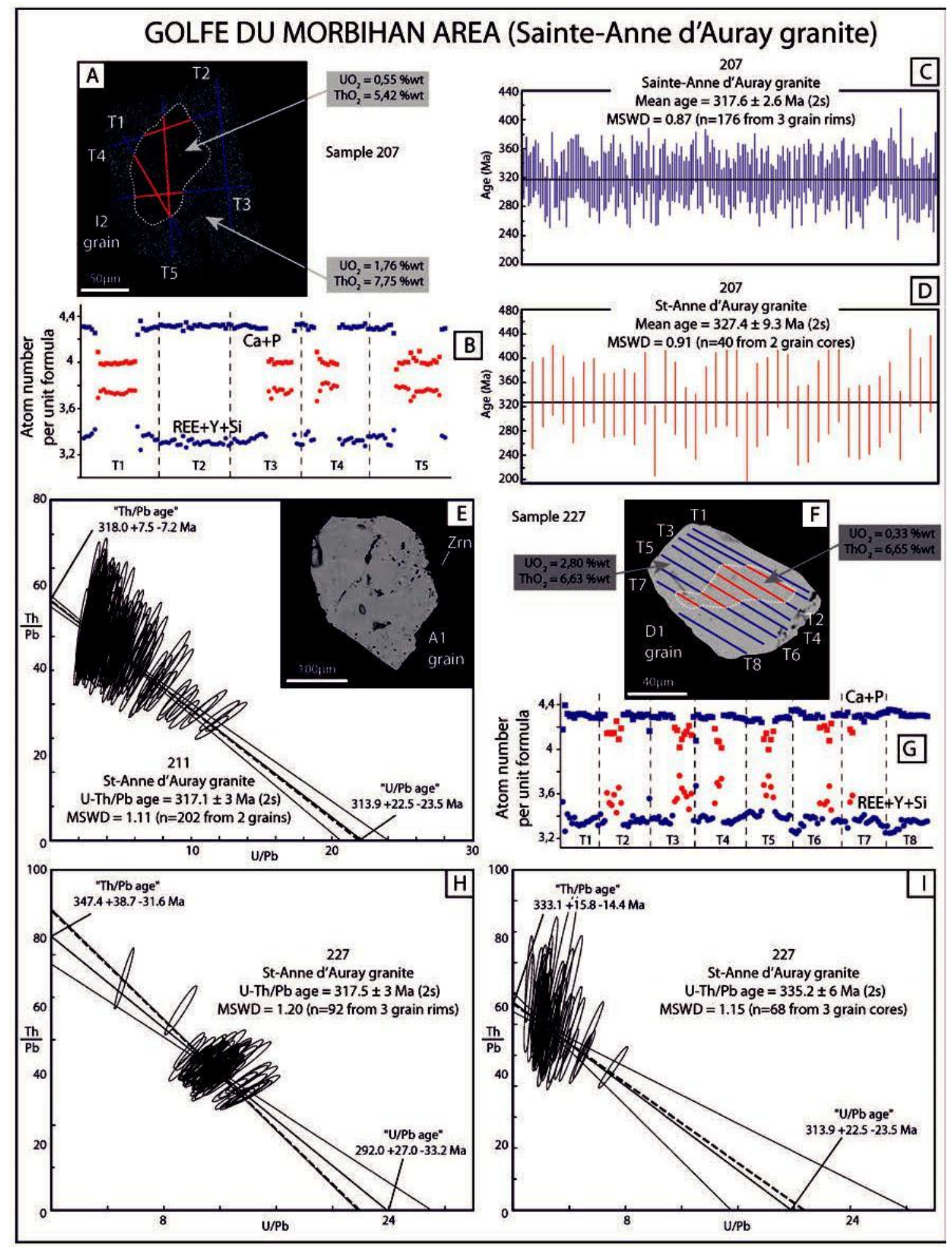

FIG. 6. - Geochronological results from Sainte-Anne d'Auray granite samples collected in the Golfe du Morbihan area. Details may be found in the caption of figure 5. For sample 207, weighted average ages are presented for the rim (C) and the core (D), as the weak chemical variations preclude isochron age calculation. Thick line corresponds to the mean age. Error bars are plotted at 2s. Mineral abbreviations are after Whitney and Evans [2010] 
mantle-core texture in accordance with the significant differences of Th content between the core and the rim (fig. 8b). In addition, the core presents low $\mathrm{Ca}$ and $\mathrm{P}$ contents and high REE, $\mathrm{Y}$ and $\mathrm{Si}$ contents, whereas the rim is relatively rich in $\mathrm{Ca}$ and $\mathrm{P}$ and relatively poor in $\mathrm{REE}, \mathrm{Y}$ and $\mathrm{Si}$ (fig. $8 \mathrm{c}$ ). Hence, two $\mathrm{Th} / \mathrm{Pb}$ versus $\mathrm{U} / \mathrm{Pb}$ plots have been produced. For the rim, the $\mathrm{Th} / \mathrm{Pb}$ and $\mathrm{U} / \mathrm{Pb}$ ratios are grouped, providing a significant error for the best-fit line. This latter one is parallel to the theoretical isochron, though, and we have calculated an isochron $\mathrm{U}-\mathrm{Th} / \mathrm{Pb}$ age at $323 \pm 6 \mathrm{Ma}$ (fig. 8d). Conversely, individual $\mathrm{Th} / \mathrm{Pb}$ and $\mathrm{U} / \mathrm{Pb}$ ratios from the core display a linear dispersion, which provides robust constraints for the best-fit line. The best-fit line parallels the theoretical isochron, yielding an isochron $\mathrm{U}-\mathrm{Th} / \mathrm{Pb}$ age at $330 \pm 5 \mathrm{Ma}$ (fig. 8e). Sample QUP03 also contains large euhedral monazite grains (up to $300 \mu \mathrm{m}$ ), but no textural or composition zoning has been found. Although the $\mathrm{Th} / \mathrm{Pb}$ and $\mathrm{U} / \mathrm{Pb}$ ratios are divided into two different groups, the best-fit line presents a relatively narrow error envelope and parallels the theoretical isochron. Hence an isochron $\mathrm{U}-\mathrm{Th} / \mathrm{Pb}$ age at $335 \pm 6 \mathrm{Ma}$ has been calculated (fig. 8f). Sample QUP04 contains large monazite grains (up to 300 $\mu \mathrm{m})$ that are often euhedral and present mantle-core texture superimposed to growth zoning (fig. $8 \mathrm{~g}$ ). The rim is slightly lighter than the core because of higher $U$ content. In addition, other elements incorporated in the monazite composition argue for a two-stage grain crystallization, with a rim rich in $\mathrm{Ca}$ and $\mathrm{P}$ and a core rich in REE, Y and Si (fig. 8h). For the rim, the $\mathrm{Th} / \mathrm{Pb}$ and $\mathrm{U} / \mathrm{Pb}$ ratios are sepa-rated into two different groups, but the best-fit line is well constrained. This latter one is similar within error to the theoretical isochron and we have calculated an isochron $\mathrm{U}-\mathrm{Th} / \mathrm{Pb}$ age at $320 \pm 4 \mathrm{Ma}$ (fig. 8i). Conversely, the range of the $\mathrm{Th} / \mathrm{Pb}$ and $\mathrm{U} / \mathrm{Pb}$ ratios is wide and a larger error for the best-fit line is observed. The best-fit line parallels the theoretical isochron, though. Hence, an isochron $\mathrm{U}-\mathrm{Th} / \mathrm{Pb}$ age at $328 \pm 6 \mathrm{Ma}$ has been calculated (fig. $9 \mathrm{j}$ ).

\section{The Hennebont-Quimperlé area}

Sample VA0609 contains monazite grains ranging from $60 \mu \mathrm{m}$ to $100 \mu \mathrm{m}$. The grains are included in biotite flakes or set at the boundary between quartz and feldspar. They display an apparent rim (darker in SEM images), which may correspond to post-crystallization alteration due to iron (hydro-) oxides mixtures (fig. 9a). Individual microprobe analyses from these rim domains have been excluded from the isochron $\mathrm{U}-\mathrm{Th} / \mathrm{Pb}$ age calculation. The $\mathrm{Th} / \mathrm{Pb}$ and $\mathrm{U} / \mathrm{Pb}$ ratios present important variations giving a good constraint for the best-fit line that is very close to the theoretical isochron. An isochron $\mathrm{U}-\mathrm{Th} / \mathrm{Pb}$ age has been calculated at $319 \pm 5 \mathrm{Ma}$ (fig. 9a). Conversely, sample VA0709 contains small monazite grains (i.e. less than $60 \mu \mathrm{m}$ ) that were repeatedly observed as biotite inclusions. SEM imaging does not reveal internal zoning, as $\mathrm{U}$ and $\mathrm{Th}$ contents are relatively constant (fig. 9b). But variations of others elements are significant and $\mathrm{a} \mathrm{Ca}$ and $\mathrm{P}$-poor core was distinguished from a $\mathrm{Y}$ and Si-rich rim (fig. 9c). The separation of the two inferred populations provides two different isochron $\mathrm{U}-\mathrm{Th} / \mathrm{Pb}$ ages, which meets the validity criteria despite a narrow range for $\mathrm{Th} / \mathrm{Pb}$ and $\mathrm{U} / \mathrm{Pb}$ ratios. For the rim, an isochron $\mathrm{U}-\mathrm{Th} / \mathrm{Pb}$ age has been calculated at $318 \pm 4 \mathrm{Ma}$ (fig. 9d), whereas the isochron $\mathrm{U}-\mathrm{Th} / \mathrm{Pb}$ age of the core is $328 \pm 6 \mathrm{Ma}$ (fig. $9 \mathrm{e}$ ).

\section{Migmatite samples from the Vilaine Estuary area}

Sample VA1409 presents monazite, whose size ranges between $50 \mu \mathrm{m}$ and $100 \mu \mathrm{m}$. The grains are often interstitial and set between chloritised biotite, quartz and feldspar. Growth, patch and mantle-core zoning (fig. 9f) have been observed, but no significant variations of the element contents were observed. Conversely, the range of the $\mathrm{Th} / \mathrm{Pb}$ and $\mathrm{U} / \mathrm{Pb}$ ratios is wide and the well-constrained best-fit line parallels the theoretical isochron, yielding an isochron $\mathrm{U}-\mathrm{Th} / \mathrm{Pb}$ age at $318 \pm 2 \mathrm{Ma}$ (fig. 9f). Sample VA1309 contains large monazite crystals (up to $150 \mu \mathrm{m}$ ). Monazite occurs as sub-rounded grains, without prominent internal zoning and mostly included in biotite, but also as set between quartz and feldspar. The relatively large range of the $\mathrm{Th} / \mathrm{Pb}$ and $\mathrm{U} / \mathrm{Pb}$ ratios provides a good constraint for the best-fit line that is parallel to the theoretical isochron. An isochron $\mathrm{U}-\mathrm{Th} / \mathrm{Pb}$ age has been calculated at $326 \pm 5 \mathrm{Ma}$ (fig. 9g).

\section{Migmatite samples from the St-Nazaire area}

Sample GnIP03 contains various-sized sub-euhedral monazite grains $(30 \mu \mathrm{m}$ to $200 \mu \mathrm{m})$ set between quartz and feldspar or included in biotite. It is worth to notice that each grain presents evidence of incipient alteration (corrosion and dissolution) along crystal cleavage, possibly due to late weathering. Monazite is associated with apatite and zircon (fig. 10a). In $\mathrm{Th} / \mathrm{Pb}$ versus $\mathrm{U} / \mathrm{Pb}$ plot, individual data are well scattered and constrain a best-fit line parallel to the theoretical isochron. We have calculated an isochron $\mathrm{U}-\mathrm{Th} / \mathrm{Pb}$ age at $328 \pm 4 \mathrm{Ma}$ (fig. 10a). Sample VA1909 presents two morphological types of monazite. The first type is characterised by very large crystals of sub-rounded monazite (up to $300 \mu \mathrm{m}$ ) sometimes with dissolution evi-dence at the quartz, feldspar and biotite grain boundaries (fig. 10b). Conversely, the second type is characterised by rare, medium-sized euhedral monazite (80 $\mu \mathrm{m}$ ) included in biotite is rarely observed (fig. 10c). Beyond morphological differences, each population presents distinct composition.

The large monazite grains present significant internal element variations within a grain, with low contents in $\mathrm{Ca}$ and $\mathrm{P}$ and high contents in LREE, $\mathrm{Y}$ and Si. Conversely, the small monazite grains present regular element compositions characterized by high $\mathrm{Ca}$ and $\mathrm{P}$ contents and low LREE, Y and $\mathrm{Si}$ contents (fig. 10d). The population composed by the large monazite present weak variations of the $\mathrm{Th} / \mathrm{Pb}$ and $\mathrm{U} / \mathrm{Pb}$ ratios, but the number of individual data (122) well constrains the position of the best-fit line and its error. Hence, the best-fit line is similar within error to the theoretical isochron, yielding an isochron $\mathrm{U}-\mathrm{Th} / \mathrm{Pb}$ age at $331 \pm$ $3 \mathrm{Ma}$ (fig. 10e). For the population of small monazite grains, $\mathrm{Th} / \mathrm{Pb}$ and $\mathrm{U} / \mathrm{Pb}$ ratios slightly vary and the best-fit line presents a large envelope error, which encompasses the theoretical isochron. An isochron $\mathrm{U}-\mathrm{Th} / \mathrm{Pb}$ age has been calculated at $319 \pm 4 \mathrm{Ma}$ (fig. 10f). Sample VA1809 is a restite that contains medium-sized sub-euhedral monazite grains (ca. $100 \mu \mathrm{m}$ ) set at the boundary between quartz and feldspar or included in quartz, feldspar and chloritised biotite. The range of the $\mathrm{Th} / \mathrm{Pb}$ and $\mathrm{U} / \mathrm{Pb}$ ratios is wide and the best-fit line is well constrained. This latter one is similar within error to the theoretical isochron, providing an isochron $\mathrm{U}-\mathrm{Th} / \mathrm{Pb}$ age at $352 \pm 10 \mathrm{Ma}$ (fig. $10 \mathrm{~g}$ ). 


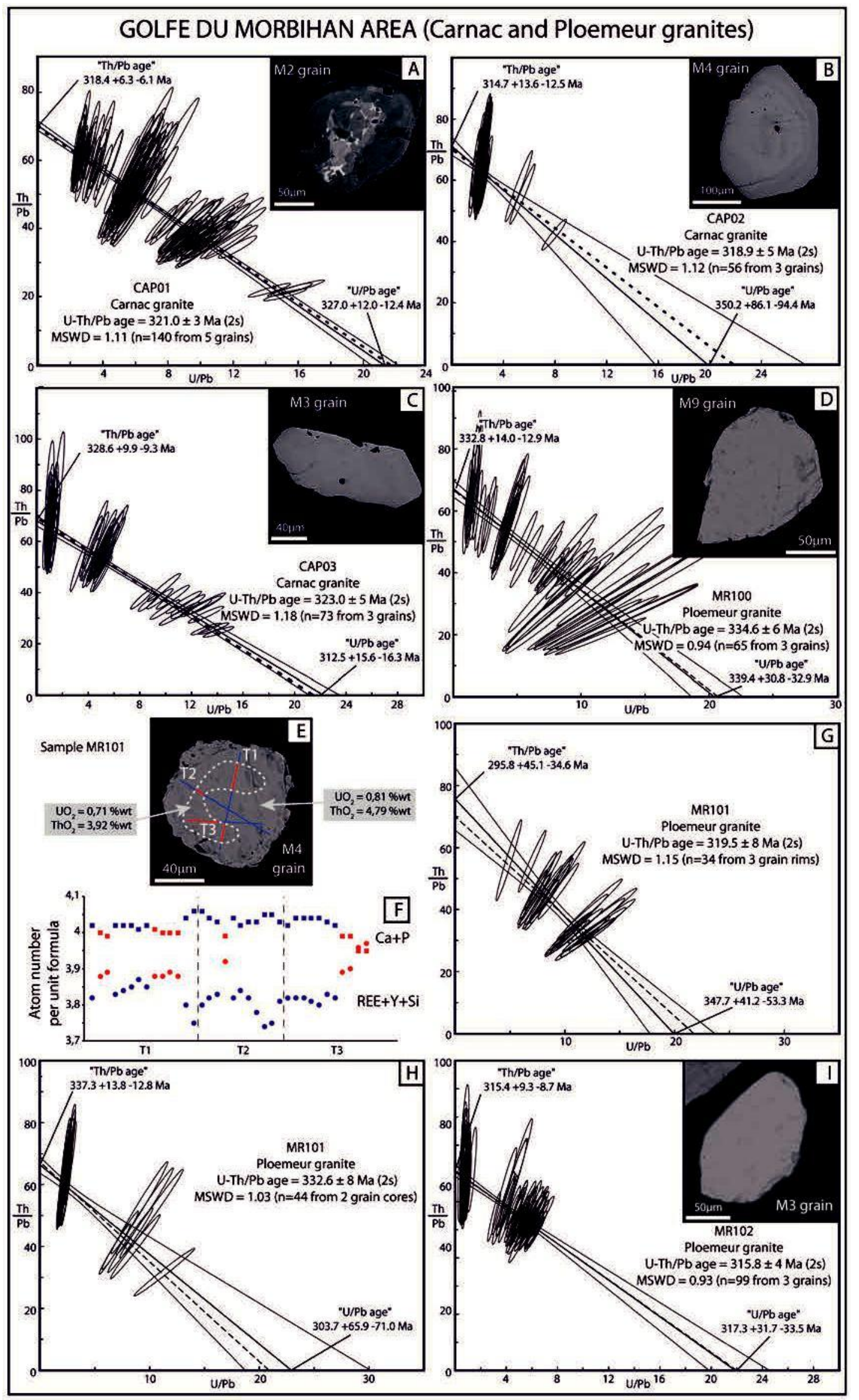

FIG. 7. - U-Th/Pb geochronological results from Carnac (A to C) and Ploemeur (D to I) granites collected in the Golfe du Morbihan area. Details are given in the caption of figure 5 . 


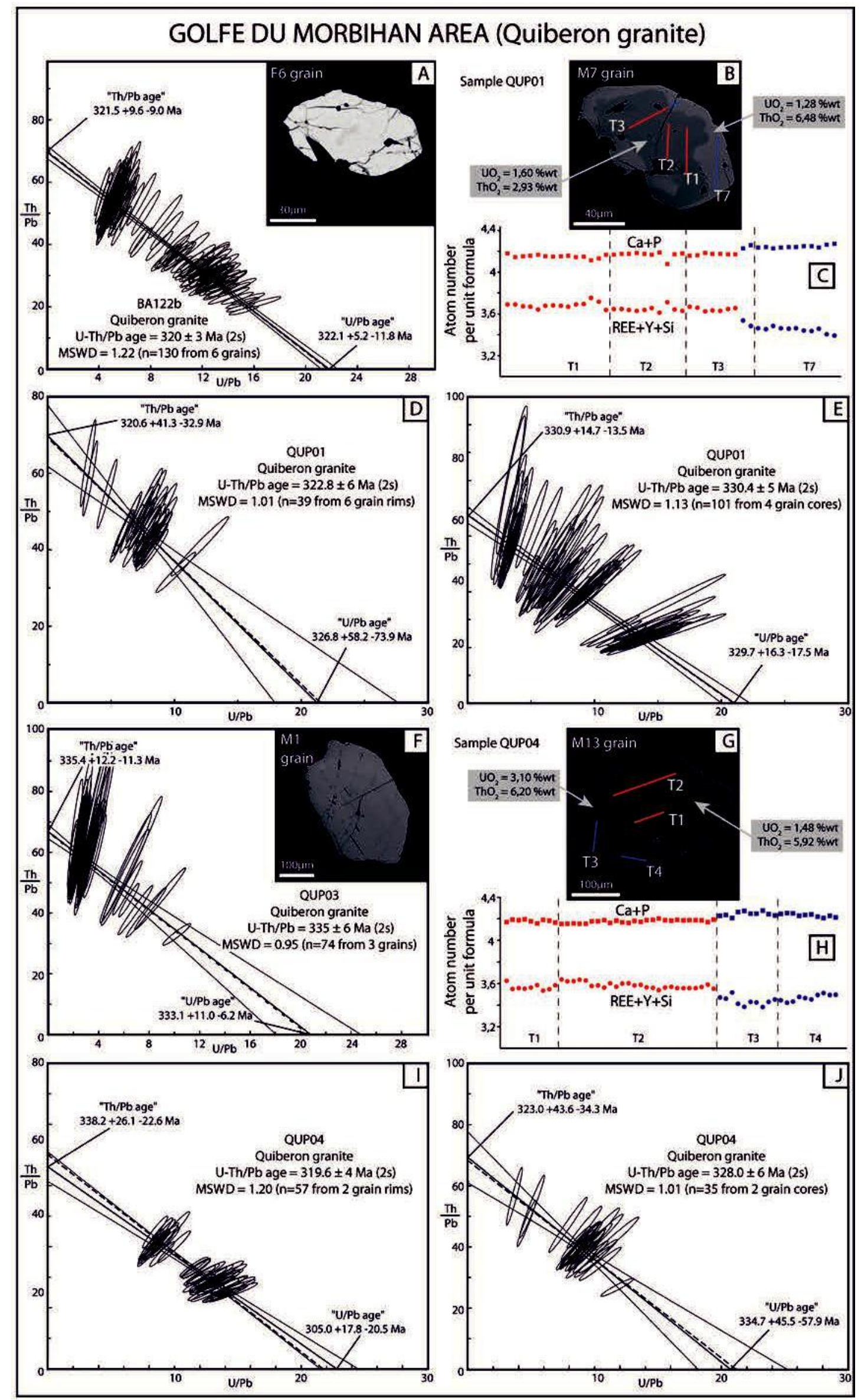

FIG. 8. - U-Th/Pb geochronological results from Quiberon granite samples collected in the Golfe du Morbihan area. Details are given in the caption of figure 5. 


\section{The Sables d'Olonne area}

Samples SP0710 and SP07bis10 contain euhedral to subrounded monazite grains, with variable size (up to $200 \mu \mathrm{m}$ in sample SP0710 and less than $60 \mu \mathrm{m}$ in sample SP07bis10). In sample SP0710, the grains are set between quartz, feldspar and biotite, whereas in sample SP07bis10, they may also be located as inclusions in biotite. Although both samples present different ranges and distributions of the $\mathrm{Th} / \mathrm{Pb}$ and $\mathrm{U} / \mathrm{Pb}$ ratios, the best-fit lines are robust and parallel the respective theoretical isochron. Hence we have calculated an isochron U$\mathrm{Th} / \mathrm{Pb}$ age at $320 \pm 5 \mathrm{Ma}$ for sam-ple SP0710 (fig. 10h) and an isochron $\mathrm{U}-\mathrm{Th} / \mathrm{Pb}$ age at $323 \pm 6 \mathrm{Ma}$ for sample SP07bis10 (fig. 10i). The spatially (and probably genetically) associated granite sample (sample SP0610) contains small sub-rounded monazite grains (less than $50 \mu \mathrm{m}$ ), which often occur at the boundary between quartz, feldspar and muscovite, or rarely trapped as inclu-sion in the muscovite. The $\mathrm{Th} / \mathrm{Pb}$ and $\mathrm{U} / \mathrm{Pb}$ ratios are well distributed and provide excellent constrains for the best-fit line. This latter one is similar within error to the theoretical isochron, yielding an isochron $\mathrm{U}-\mathrm{Th} / \mathrm{Pb}$ age at $328 \pm$ $4 \mathrm{Ma}$ for sample SP0610 (fig. 10j).

\section{INTERPRETATIONS : RELIABILITY AND SIGNIFICANCE OF THE AGE DATA}

EPMA U-Th/Pb chemical dating of monazite has become an increasingly popular, non-destructive and in situ method providing high-resolution texturally-controlled ages. This method was successfully applied to various types of mag-matic and metamorphic rocks, including migmatites [e.g. Cocherie et al., 2005; Be Mezeme 2005; Be Mezeme et al., 2006; Faure et al., 2008a, 2010; Gagné et al., 2009; Majka et al., 2012]. While new geochronological constraints were accumulated and data reduction methods were refined, the significance of the ages was questioned, as conditions of monazite crystallization remain not clearly understood, es-pecially for metamorphic monazite [e.g. Vavra et al., 1996; Forster et al., 2000, 2002; Forster and Parrish, 2003; Pyle and Spear, 2003; Goncalves et al., 2004; Pyle, 2006; Kelsey et al., 2008; Janots et al., 2009]. In the following, the reli-ability of the calculated ages and their significance are dis-cussed in term of geological events, in the light of the present knowledge of monazite chemical system.

\section{Reliability of ages}

Reliability of the U-Th/Pb chemical ages is based on two main assumptions related to the intrinsic mineral structure of monazite [Suzuki and Adachi, 1991] including that 1) common $\mathrm{Pb}$ is negligible compared to the amount of thorogenic and uranogenic $\mathrm{Pb}$ [Parrish, 1990; Cocherie et al., 1998] and 2) no radiogenic $\mathrm{Pb}$ loss has occurred since the closure of the system [e.g. Smith and Giletti, 1997; Cherniak et al., 2004; SeydouxGuillaume et al., 2002; Gardés et al., 2006]. These hypotheses were verified on nat-ural samples by numerous studies, where results obtained by the chemical method were compared to isotopic tech-niques like TIMS, SIMS and LA-ICPMS [i.e. Cocherie et al., 1998; 2005; Montel et al., 2002].

The isochron method [Cocherie and Albarède, 2001; Cocherie et al., 2005] was used to represent the individual ages and to compute an isochron age for each sample. This method requires a variation of the $\mathrm{Th} / \mathrm{U}$ ratio to provide a large data span in the $\mathrm{Th} / \mathrm{Pb}$ vs. U/Pb diagram, constraining the error envelop of the best-fit line. According to [Cocherie et al., 2005] the computed regression must satisfy 3 criteria: 1) the theoretical isochron age must be comprised in the error envelop of the best-fit line and must crosscut each individual data within the ellipse error; 2) the calculated MSWD must be lower than the statistical param-eter [Wendt and Carl, 1991] and 3) the two intercept ages (i.e. $\mathrm{Th} / \mathrm{Pb}$ and $\mathrm{U} / \mathrm{Pb}$ ages) must be similar within error. These conditions were satisfied for all samples except for sample 207 that presents very low variations of the $\mathrm{Th} / \mathrm{U}$ ra-tio. In this case, the weighted mean age method was used as an alternative age calculation procedure. Similarly to the isochron method, the calculated age is statistically accept-able, since, for a given population, the calculated MSWD value falls below the deviation parameter (table I) [Wendt and Carl, 1991]. This method assumes that age errors are symmetric, producing ages, which are usually younger (ca. 3 to $5 \mathrm{Ma}$ ) than the age obtained from other methods [Be Mezeme, 2005].

\section{Classification of the monazite grains from the dataset}

Validation of all criteria of the $\mathrm{U}-\mathrm{Th} / \mathrm{Pb}$ chemical dating method allows interpreting each calculated age (weighted mean and isochron age) as related to a single geological event. However, monazite grains present morphological and chemical differences and provide a variety of ages for monazite (re-) crystallisation (table I). The occurrence of growth zoning among numerous analyzed grains suggests a more intricate crystallisation evolution for monazite crys-tals, which cannot be portrayed with the time resolution of present geochronological tools. Depending on crystal habits and composition together with phase-relationships, five types of monazite (A1 and A2 types for migmatite, B1, B2 and B3 types for granite) have been recognized as following (fig. 2).

- A1-type monazite grains of various sizes that occur either included in biotite flakes or set at the boundary be-tween quartz and feldspar in the leucosome (migmatite samples VA0609, VA1009, 201B, 220A, 220B, SP0710, SP07bis10, VA1409, VA1309 and GnIP03). Although growth, patchy and mantle-core zoning have been some-times observed among the samples, only one population has been distinguished and a single age for each sample has been calculated. The ages range from $326 \pm 5 \mathrm{Ma}$ to $318 \pm 6 \mathrm{Ma}$ (table I). For sample GnIP03 (migmatitic gneiss), we cannot ascertain the significance of the age $(328 \pm 4 \mathrm{Ma})$, as both melanosome and leucosome parts were collected to-gether. Despite a partial overlap of ages within error brack-ets, this rather old age could show mixing between two age populations of monazite, without significant composition variations.

- A2-type contains small to medium-sized monazites that occur either at grain boundary or enclosed in biotite and garnet in the restite (samples 220H, 221C and VA1809). No internal zoning has been revealed. The calcu-lated ages range between $352 \pm 10$ and $332 \pm 6 \mathrm{Ma}$ and (ta-ble I) that is significantly older than the ages provided by the monazite of the leucosomes. 
- Sample VA1909 presents two populations of monazite (table I). Euhedral small grains of medium-sized monazite sharing similarities with A1-type monazite are included in biotite, whereas large crystals of sub-rounded monazite similar to A2-type monazite are set at grain boundaries and present evidence of corrosion. Each population presents distinct contents in $\mathrm{Ca}, \mathrm{P}, \mathrm{LREE}, \mathrm{Y}$ and $\mathrm{Si}$. The age of the population marked by the small grains $(319 \pm 4 \mathrm{Ma})$ is consistent with the age of other leucosome samples. The old age (331 $\pm 3 \mathrm{Ma})$ is very similar to the age of restite samples.

- Sub-euhedral to euhedral B1-type monazite up to $300 \mu \mathrm{m}$ was identified in granite samples BA122b, MR102, CAP01, CAP02, CAP03, and 211. The grains that display growth zoning occur at the boundary between quartz, feldspar and muscovite. The calculated ages range from $316 \pm$ 4 Ma to $323 \pm 5 \mathrm{Ma}$ (table I).

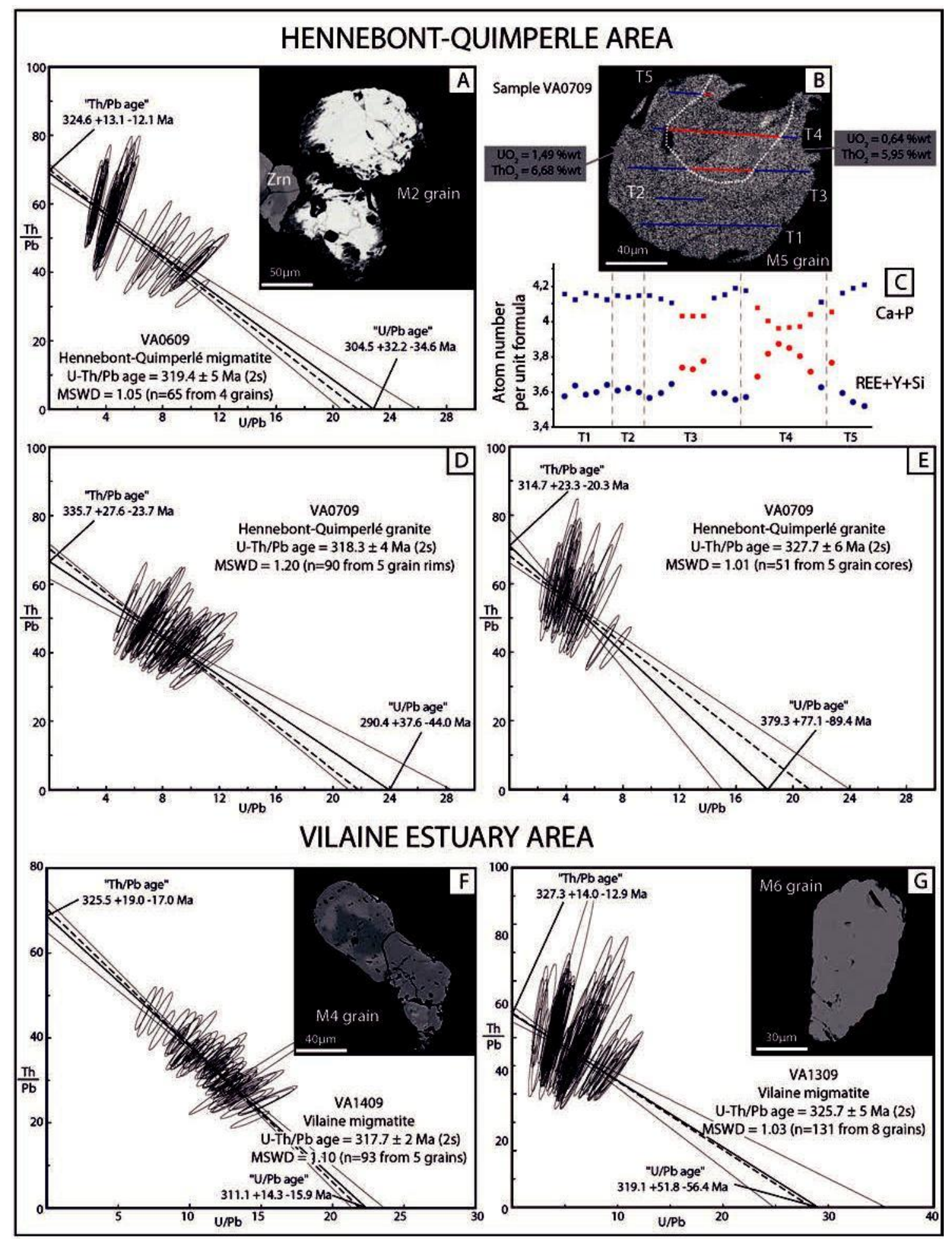

FIG. 9. - U-Th/Pb geochronological results from migmatite and granite samples collected in the Hennebont-Quimperlé (A to E) and the Vilaine Estuary areas. Details are given in the caption of figure 5. 
-B2-type monazite, with a magmatic rim and an inher-ited core was identified in granite samples QUP01, QUP04, MR101, 207, 227 and VA0709. The grains are usually euhedral, medium to large in size. They occur as inclusions in biotite or at the grain boundary between quartz, feldspar and mica. Due to repeatedly observed low variations of $U$

and Th contents, mantle-core textures were not systematically observed on BSE images. However, obvious variations

of the $\mathrm{Ca}, \mathrm{P}, \mathrm{Si}, \mathrm{REE}$ and $\mathrm{Y}$ contents and significant differ-

ences in the degree of chemical substitution help to distin-

guish a core from a rim. The core presents a sub-rounded

shape, showing embayment-like textures. It is always low in

$\mathrm{Ca}$ and $\mathrm{P}$ and rich in REE, $\mathrm{Y}$ and Si. Conversely, the rim is

marked by euhedral shape and internal growth zoning has

been observed for some grains. Rim and core populations

often present different ranges of value for the U/Th ratio.

The age of the rim vary between $323 \pm 6 \mathrm{Ma}$ and $317 \pm$

$3 \mathrm{Ma}$, whereas the age of the core is bracketed between

$335 \pm 6 \mathrm{Ma}$ and $327 \pm 9 \mathrm{Ma}($ table I).

- B3-type monazite was identified in granite samples QUP03, MR100, and SP0610. The grains are generally small (except for sample QUP03) and often occur included in biotite or rarely at grain boundary between quartz and feldspar. The grains do not present internal zoning, such as growth zoning. The isochron $\mathrm{U}-\mathrm{Th} / \mathrm{Pb}$ ages are bracketed between $338 \pm 9 \mathrm{Ma}$ and $328 \pm 4 \mathrm{Ma}$ (table I).

\section{Geological significance of the calculated ages}

Monazite has been proposed to resist dissolution at temperatures up to $900^{\circ} \mathrm{C}$ [Braun et al., 1998; Cherniak et al., 2004], ensuring, at least partially its preservation in the studied rocks [Brown, 1983; Jones and Brown, 1989, 1990;

Goujou, 1992; Brown and Dallmeyer, 1996; Marchildon and Brown, 2003; Johnson $\quad$ and Brown, 2004]. A2-type monazites from restite present ages ranging between $352 \mathrm{Ma}$ and $332 \mathrm{Ma}$. This age group may represent inherited pre-partial-melting stages, either during the prograde evolution of the rocks, or during an early metamorphic event. Melt extraction and formation of the leucosomes may also provoke encapsulating of these old monazite grains. In addition, monazite solubility remains generally limited in peraluminous melts [Montel, 1986; 1987; 1993] allowing the persistence of round-shaped old monazite grains in the leucosome. In this case of partial dissolution, new grains of monazite may crystallise, while melt cools to form the leucosome [Hawkins and Bowring, 1999; Rubatto et al., 2001; Kohn et al., 2005]. The 326-318 Ma ages of A1-type

TABLE I. - Results of U-Th/Pb geochronology on monazite.

MSWD is the calculated mean square weighted deviation; DP is theoretical deviation parameter [Wendt and Carl, 1991]. All ages are isochron ages, except for sample 207 (spotted by *) for which a weighted average age has been calculated

\begin{tabular}{|c|c|c|c|c|c|c|c|}
\hline Area & Type & Massif & $\mathrm{X}$ Long $\left({ }^{\circ}\right)$ & Y Long $\left({ }^{\circ}\right)$ & Sample & Age (Texlure/Structure) & MSWD/DP \\
\hline \multirow{19}{*}{ Golle du Morbihan } & \multirow{13}{*}{ 莺 } & \multirow{3}{*}{ 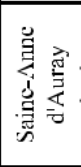 } & -2.76687 & 47.69901 & 207 & $\begin{array}{l}318 \perp 3 \mathrm{Ma} \text { (Rim) } \\
327=9 \mathrm{Ma} \text { (Core) }\end{array}$ & $\begin{array}{l}0.87 / 1.21 \\
0.91 / 1.45 \\
\end{array}$ \\
\hline & & & -2.64583 & 47.62890 & 211 & $317-6 \mathrm{Ma}$ & $1.11 / 1.20$ \\
\hline & & & -2.62172 & 47.63511 & 227 & $\begin{array}{l}317 \pm 3 \mathrm{Ma} \text { (Rim) } \\
335 \text { - } 6 \mathrm{Ma} \text { (Core) } \\
\end{array}$ & $\begin{array}{l}1.20 / 1.30 \\
1.15 / 1.35 \\
\end{array}$ \\
\hline & & \multirow{3}{*}{ 总 } & $-2,99442$ & 47,64120 & $\mathrm{CAP} 01$ & $321+3 \mathrm{Ma}$ & $1.11 / 1.24$ \\
\hline & & & -3.02187 & 47.59121 & $\mathrm{C} \triangle \mathrm{P} 02$ & $319+5 \mathrm{Ma}$ & $1.12 / 1.38$ \\
\hline & & & -3.10194 & 47.66289 & CAP03 & $323 \perp 5 \mathrm{Ma}$ & $1.18 / 1.33$ \\
\hline & & \multirow{3}{*}{ 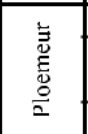 } & -3.47818 & 47.71515 & MR100 & $335 \pm 7 \mathrm{Ma}$ & $0.94 / 1.35$ \\
\hline & & & $-3,41500$ & 47.70031 & MR101 & $\begin{array}{l}320 \pm 8 \mathrm{Ma} \\
333 \pm 8 \mathrm{Ma}\end{array}$ & $\begin{array}{l}1.15 / 1.49 \\
1.03 / 1.43 \\
\end{array}$ \\
\hline & & & -3.40333 & 47.73311 & MR102 & $316 \perp 4 \mathrm{Ma}$ & $0.93 / 1.29$ \\
\hline & & \multirow{4}{*}{$\begin{array}{l}\vdots \\
\overline{2} \\
\stackrel{0}{\Xi} \\
\vdots\end{array}$} & -3.12964 & 47.52340 & BA122b & $320 \pm 3 \mathrm{Ma}$ & $1.20 / 1.25$ \\
\hline & & & -3.13143 & 47.53810 & QUP01 & $\begin{array}{l}323+6 \mathrm{Ma} \\
330 \pm 5 \mathrm{Ma}\end{array}$ & $\begin{array}{l}1.01 / 1.46 \\
1.13 / 1.28\end{array}$ \\
\hline & & & -3.12867 & 47.52501 & QUP03 & $335 \pm 6 \mathrm{Ma}$ & $0.95 / 1.33$ \\
\hline & & & -3.11828 & 47.49780 & QUP04 & $\begin{array}{l}320 \pm 4 \mathrm{Ma} \\
328+6 \mathrm{Ma}\end{array}$ & $\begin{array}{l}1.20 / 1.38 \\
1.01 / 1.49\end{array}$ \\
\hline & \multirow{6}{*}{ 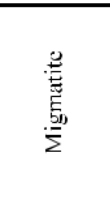 } & & -3.14948 & 47.71601 & VA1009 & $325 \pm 6 \mathrm{Ma}$ (leucosome) & $1.09 / 1.27$ \\
\hline & & & -2.91310 & 47.54286 & 201B & $325 \pm 6 \mathrm{Ma}$ (leucosome) & $0.66 / 1.26$ \\
\hline & & & -2.86416 & 47.61073 & $220 \mathrm{~A}$ & $323 \pm 6 \mathrm{Ma}$ (leucosome) & $0.69 / 1.29$ \\
\hline & & & -2.86417 & 47.61074 & $220 \mathrm{~B}$ & $320 \pm 5 \mathrm{Ma}$ (leucosome) & $0.70 / 1.26$ \\
\hline & & & -2.86418 & 47.61075 & $220 \mathrm{H}$ & $332 \pm 6 \mathrm{Ma}$ (restite) & $0.87 / 1.28$ \\
\hline & & & -2.80013 & 47.61833 & $221 \mathrm{C}$ & $338 \pm 8 \mathrm{Ma}$ (restite) & $0.92 / 1.34$ \\
\hline \multirow[t]{2}{*}{ Ilennebont-Quimperlé } & Granile & & -3.39141 & 47.83899 & VA0709 & $\begin{array}{l}318 \perp 4 \mathrm{Ma} \text { (Rim) } \\
328=6 \mathrm{Ma} \text { (Core) }\end{array}$ & $\begin{array}{l}1.20 / 1.30 \\
1.01 / 1.40\end{array}$ \\
\hline & Migmatitc & & -3.39511 & 47.83585 & VA0609 & $319-5 \mathrm{Ma}$ (lcucosome) & $1.05 / 1.35$ \\
\hline \multirow{2}{*}{ Vilaine River Mouth } & \multirow{2}{*}{ Migmatite } & & -2.45181 & 47.54941 & VA1409 & $318 \perp 2 \mathrm{Ma}$ (leucosome) & $1.10 / 1.29$ \\
\hline & & & -2.48122 & 47.55001 & VA1309 & $326 \pm 5 \mathrm{Ma}$ (leucosome) & $1.03 / 1.25$ \\
\hline \multirow[b]{2}{*}{ St-Nazaire Dome } & \multirow[b]{2}{*}{ Migmatitc } & & -2.46636 & 47.27041 & GnIP03 & $328 \perp 4 \mathrm{Ma}$ (leucosome) & $1.20 / 1.37$ \\
\hline & & & -2.30674 & 47.23741 & VA1 909 & $331 \pm 3 \mathrm{Ma}$ (large grains) & $1.02 / 1.26$ \\
\hline
\end{tabular}



monazite, collected from leucosomes are interpreted as melt crystallisation ages. As monazite corrosion by the melt is limited to the grain boundary [Braun et al., 1998], mixture of A1-type and A2-type monazites may occur in the leucosome as for sample VA1909.

The occurrence of monazite in granitic rocks depends mainly on the availability of REE and actinides content of the original magma [Förster, 1998]. Because of their com-position, peraluminous granites usually host a significant fraction of monazite, which often crystallised at near-soli-dus conditions. B1-type monazite grains occur at grain boundary and repeatedly display growth zoning that reveals successive chemical stages during crystallisation, and inter-action between monazite growth and the melt composition evolution. Their ages (323-316 Ma) can be therefore inter-preted as the crystallization age. As the emplacement of granite pluton is characterized by a cooling period shorter than the error bars of the calculated age, it is generally as-sumed that the age of monazite crystallisation represents the age of granite intrusion [Parrish, 1990]. For several granite intrusions, B2-type monazite grains showing man-tle-core texture and the obvious differences of chemical composition between the rim and the core support crystallisation during two separate stages. Age of the rim (323-317 Ma) is consistent with the age of B1-type monazite, whereas the ages of grain core are significantly older (335-327 Ma). While core ages may represent an in-herited magmatic or metamorphic event, rim ages are inter-preted as the late crystallisation episode, coeval with melt cooling and pluton emplacement. Pre-anatectic monazite may therefore be preserved and coexists with grains formed during late magmatic events. If the melt contains sufficient $\mathrm{P}$ and REE, a new generation of monazite can crystallise through nucleation on inherited grains. If the melt is poor in $\mathrm{P}$ and REE, no monazite will form during magma crystallisation and only inherited monazite such as B3-type monazite will be found. Their age $(338 \pm 9 \mathrm{Ma}$ to $328 \pm 4 \mathrm{Ma})$ is very similar to the core age of B2-type monazite grains; hence it may correspond to inherited, magmatic or metamorphic events.

In the lights of these results, it is proposed that sub-solidus ductile deformation and the possible associated fluid circulations did not significantly affect the $\mathrm{U}-\mathrm{Th} / \mathrm{Pb}$ system in monazite, as variously deformed samples of Ploemeur and Quiberon granites present similar ages. This observa-tion is in agreement with geochronological data from other peraluminous plutons associated to ductile shear zone that provided same U$\mathrm{Th} / \mathrm{Pb}$ isochron ages on monazite for the undeformed granite and for the mylonite [Choulet et al., 2012]. Conversely, the lack of age reset due to deformation does not comply with other $\mathrm{U}-\mathrm{Th} / \mathrm{Pb}$ isotopic ages from monazite from southern Brittany granites [Tartèse et al., 2011b], whose younger ages can be explained rather by per-vasive fluid circulations along permeable conduits than by methodological bias.

\section{AGE OF PARTIAL-MELTING AND TECTONIC IMPLICATIONS}

Among the main results of this study, textural/chemical analyses allow recognising five monazite types. However, conspicuous similarities between different types and results of the $\mathrm{U}-\mathrm{Th} / \mathrm{Pb}$ datings permit to distinguish only two genuinely different generations of monazite in both migmatites and granite rocks: i) inherited grains occur in mesosomes and melanosomes in migmatite ( $\boldsymbol{A} 2$ type), as inclusions in biotite (B3 type) or in the core of younger crystals in the granite rocks (B2 type) that yielded ca. 352-330 Ma ages and ii) newly formed grains are found in leucosomes (A1 type) and in (B1 type ) crystals and rim around old grains (B2 type) crystals settled at ca. 325-315 Ma. Implications of these ages will be now discussed in the regional and the geodynamical context.

\section{Age-constraints for the evolution of the Lower unit}

New U-Th/Pb chemical age-results provide absolute timeconstraints on the evolution of the Lower unit for the whole coastal South Armorican domain (fig. 11). In the Golfe du Morbihan area, ca. 326-318 Ma ages were obtained for A1 monazites from small-scale leucosomes within 4 migmatite samples (fig. 11), interpreted as monazite crystallisation ages during melt cooling. These results are consistent with the parallel dating at ca. $318 \pm 3$ Ma of B1 monazites from the closely associated large-scale anatectic granite massif (i.e. Sainte-Anne d'Auray). Besides, samples from 4 other migmatite sampling zones yielded crystallization ages for A1 monazites from leucosomes, clustering at ca. 326-318 Ma. Furthermore, these ages are in agreement with the scarce previous time constraints [e.g. Turrillot et al., 2009] and support a strikingly synchronous partial-melting event over the whole coastal part of South Armorican domain. Interest-ingly, the solidus was intersected during burial along a typi-cal ca. $30^{\circ} \mathrm{C} / \mathrm{Km}$ Barrovian gradient (fig. 12) [Brown, 1983; Jones and Brown, 1989, 1990; Goujou, 1992; Brown and Dallmeyer, 1996; Marchildon and Brown, 2003; Johnson and Brown, 2004]. Effective melt generation was subse-quently initiated at peak-P metamorphic conditions at ca. $8-9$ kbar for $750-800^{\circ} \mathrm{C}$ at variance with the examples of the Canadian Cordillera and the Aegean Sea, where partial-melting occurs during decompression some 20 Ma after peak-P conditions [Vanderhaeghe et al., 1999; Hinchey et al., 2006; Duchêne et al., 2006; Jolivet and Brun, 2010]. Ages of late granite intrusions, such as Carnac, Quiberon and Ploemeur granites also cluster at ca. $320 \mathrm{Ma}$, at the end of the partial-melting event at conditions of ca. $4-5 \mathrm{kbar}$ for $700-750^{\circ} \mathrm{C}$ [Johnson and Brown, 2004]. Despite clear cross-cutting relationships at mapscale (fig. 1) and limited single-age error brackets the ability to geochronologically distinguish the different late intrusive granite complexes has not been possible.

Melanosome samples (i.e. A2 monazite type) mostly yielded a subordinate age cluster at ca. 352-332 Ma, which is similar to the inherited ages, repeatedly observed in the B2 monazites from intrusive granites. Apart the ca. $352 \mathrm{Ma}$ age that may have recorded an earlier event, this older age group that significantly differs from the age of partial-melt-ing is relatively new for the South-Armorican domain. Based on microtextural and compositional criteria, this age group is believed to reflect a regional metamorphic event, related to the crossing of monazite producing reactions (fig. 12). Despite a complex behaviour of monazite during the metamorphic evolution, peak-crystallisation conditions mainly occur during increasing P-T conditions from the up-per-greenschist facies and in the amphibolite facies through 


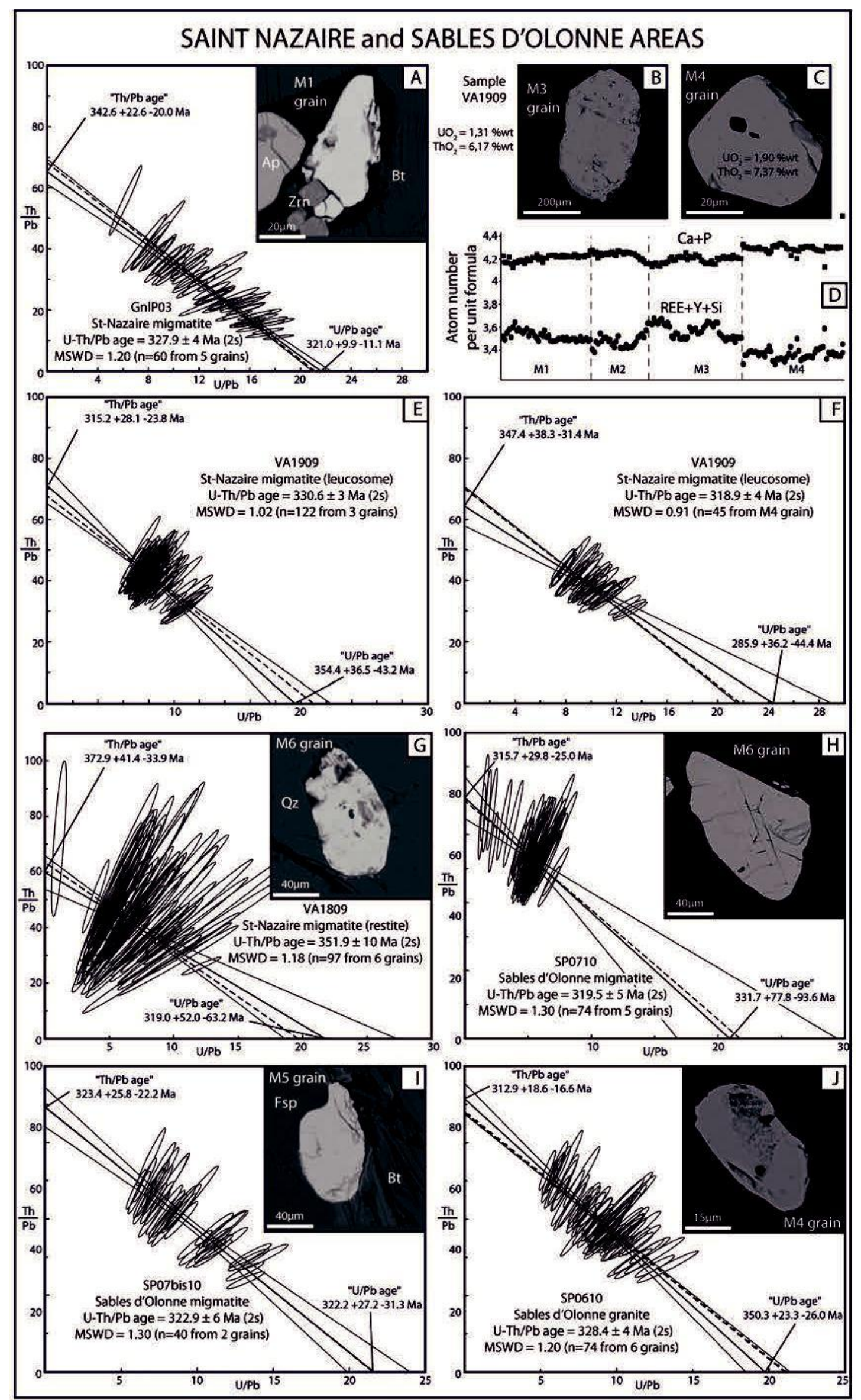

FIG. 10. - U- $\mathrm{Th} / \mathrm{Pb}$ geochronological results from migmatite samples collected in the Saint-Nazaire (A to G) and in the Sables d'Olonne areas (H to J). Details are given in the caption of figure 5 . 
monazite-producing reactions in the range of ca. 400 to $650^{\circ} \mathrm{C}$ [e.g. Smith and Barreiro, 1990; Pyle et al., 2001, Pyle, 2006; Forster et al., 2002; Janots et al., 2009; Spear, 2010]. This assumption is strengthened by a ca. $338 \pm 7$ Ma metamorphic age recently retrieved from a non-melted micaschist sample from the overlying Vilaine Estuary unit [Augier et al., 2011]. The ca. 335-330 Ma ages therefore probably record monazite crystallisation ages related to the crossing of a monazite producing reaction during increasing $\mathrm{P}-\mathrm{T}$ conditions in an overall nappe-stacking context [i.e. Goujou, 1992; Johnson and Brown, 2004; Gloaguen, 2006; Janots et al., 2009; Spear, 2010].
The ca. 325-320 Ma turning-point in the evolution of the coastal South Armorican domain

Gravitational collapse corresponds to the decay of lateral contrast in the gravitational potential energy stored within orogenic belts by gravity-driven flow and ultimately triggers crustal thinning of the orogenic crust [e.g. Rey et al., 2001; Vanderhaeghe and Teyssier, 2001]. Gravita-tional collapse appears controlled by three main mechanisms including 1) a decrease or even an inversion in the tectonic forces applied at the boundary of the orogenic system, 2) an increase of the potential energy caused by convective removal,

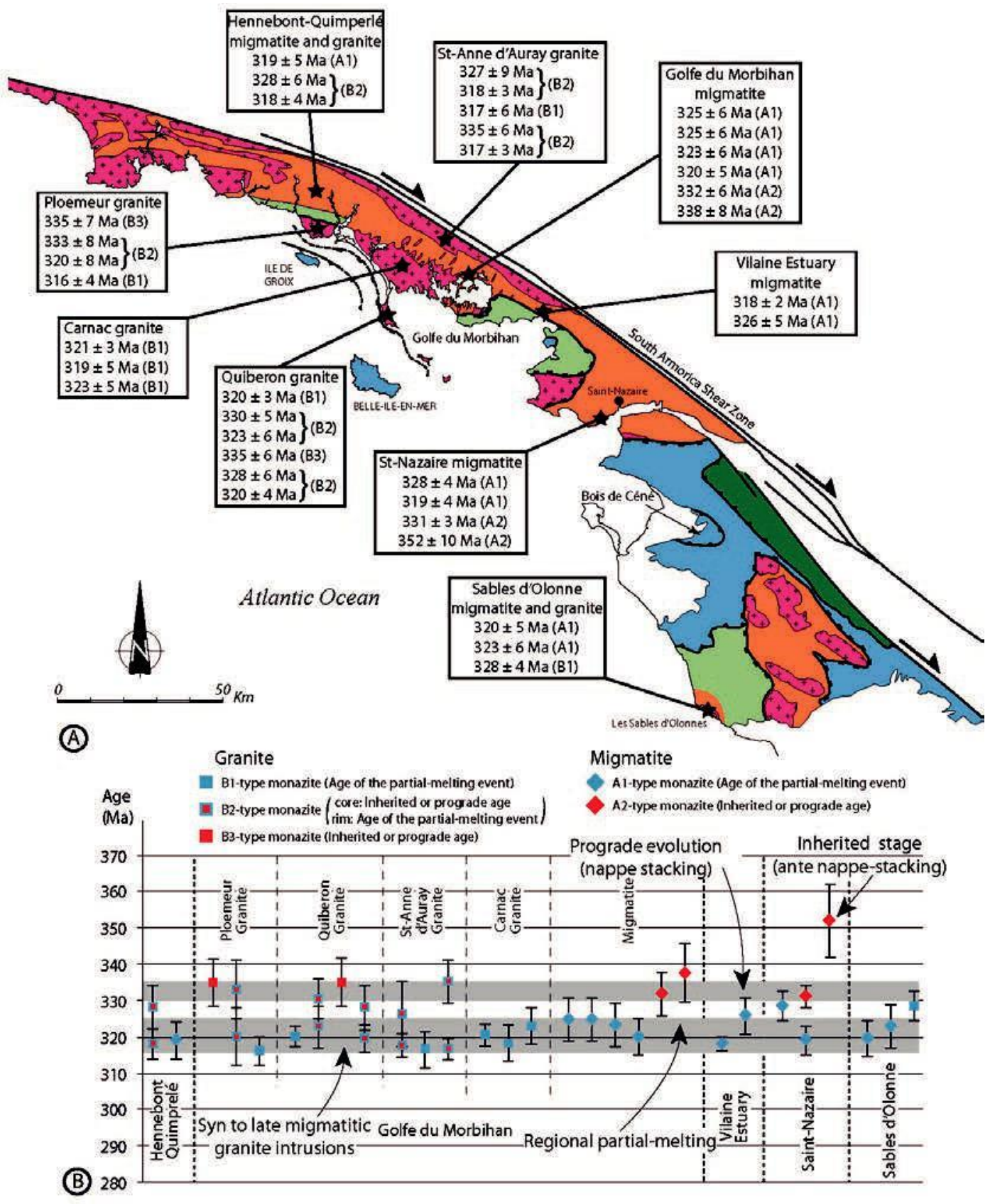

FIG. 11. - Synoptic chart of the U-Th/Pb geochronological results across the coastal South Armorican domain.

Despite local partial age overlapping, 3 different stages can be distinguished. Old inherited ages remain rare (e.g. the 352 Ma age), whereas a pre-anatectic, prograde episode probably associated to nappe-stacking is recorded throughout the study area at ca. 335-330 Ma. Partial-melting that probably starts at ca. 325 Ma, and became widespread during the 325-320 Ma period, accompanied by the accumulation of large volume of anatectic melts as anatectic granites (e.g. Sainte-Anne d'Auray granite). The ca. 320-318 Ma age is ascribed to late or even post-migmatitic granites (e.g. Carnac, Ploemeur and Quiberon granites). 
delamination of the lithospheric mantle root or slab break-off or 3) a decrease in the strength of the thickened orogenic crust due to thermal weakening thereby emphasising the role of partial-melting [e.g. Vanderhaeghe and Teyssier, 2001].

At variance with the examples of the Canadian Cordillera or the Aegean domain where 1) precise geodetic or geophysical-constraints on plate-kinematics, 2) the behaviour of the mantle or 3 ) the geometry of the continents involved in the collision are reasonably well-constrained, the case of the West-European Variscan orogenic segment is quite complex as none of these parameters is accurately constrained. Conversely, one of the most important advantages of the coastal South Armorican domain is to offer an opportunity to study deep-orogenic processes over series of crustal-scale sections and more particularly, to understand the role of partial-melting for the late-evolution of the Variscan orogenic belt.

An unexpected major result of this study is the recognition of a common, regional-scale probable signature of prograde metamorphism dated at ca. 335-330 Ma and ascribed to crystallisation ages during monazite-forming reaction(s) before partial-melting [e.g. Gloaguen, 2006; Janots et al., 2009]. A single, common ca. 326-318 Ma age-cluster was also retrieved for the melt crystallisation age following a major partial-melting event throughout the coastal South Armorican domain. Partial-melting thus occurred at regional-scale some ca. 35-40 m.y. after the youngest age of subduction-relation HP metamorphism recognised within the uppermost units [Le Hébel et al., 2002a, 2002b; Bosse et al., 2005] and ca. 20-25 m.y. after the integration of the first continental-derived units in the orogenic wedge during collision [Maillet, 1984; Colchen and Poncet, 1987; Rolin and Colchen, 2001]. Traces of initial stacking-structures are however extremely rare and heavily reworked by subsequent extensional deformation except at the top of the structural pile [e.g. Iglesias and Brun, 1976; Maillet, 1984; Goujou, 1992; Geoffroy, 1993; Le Hébel et al., 2002a, 2002b; Bosse et al., 2002, 2005]. The currently outcropping architecture of the coastal South Armorican Domain thus displays large-scale portions of Variscan lower crust heavily affected by partial-melting and pluton intrusions that were exhumed in several migmatite-cored metamorphic domes roofed by extensional shear zones [Brown, 2005; Turrillot et al., 2009; 2011a]).

As inferred from existing P-T constraints of the studied migmatite belt [Brown, 1983; Jones and Brown, 1989, 1990; Goujou, 1992; Brown and Dallmeyer, 1996; Marchildon and Brown, 2003; Johnson and Brown, 2004], the solidus was intersected during burial along a typical Barrovian collisional gradient (fig. 13) [e.g. Gardien et al., 1997]. Accordingly, inception of partial-melting at peak-P conditions therefore coincides with a major change in the tectonic regime recorded at regional-scale. The inception and drastic generalisation of partial-melting within the coastal South Armorican orogenic segment was coeval with a fast transition from net crustal thickening to net crustal thinning. Accordingly, partial-melting that must have lowered the overall strength of the orogenic crust would be an important factor facilitating the late-orogenic gravitational collapse of the Armorican orogenic segment or the Variscan belt. However, transition from compression to extension may also imply a contemporaneous change of kinematic boundary conditions. Two scenarios can then be envisaged: (1) continuous stacking of continental crustal units, rich in radiogenic elements, led to an increase of temperature within the orogenic wedge pro-voking partial-melting, the resulting drop in the crustal strength inducing lateral flow of a low-viscosity partially molten layer, like in the recent evolution of the Tibetan plateau [Nelson et al., 1996], or (2) a drastic change of the boundary conditions such as convective removal of the lithospheric mantle, or inception of slab retreat, slab detachment or tearing has induced hot asthenospheric upwelling which in turn led to coeval extension and partial-melting.

At a more local scale, interrelations between partialmelting or magmatism in a broad sense, and deformation were observed from the scale of large-scale plutons (fig. 11) to the scale of the outcrop (fig. 4g) [Cagnard et al., 2004; Turrillot et al., 2009]. Strain thus benefited of the lowstrength of the magma prior to complete crystallisation promoting intense shearing of large-scale laccoliths often referred to as synkinematic plutons [Jégouzo, 1980; Gapais et al., 1993; Tartèse et al., 2011a]. The Ploemeur-Quiberon leucogranite set of plutons is particularly exemplary of that discussion as it concentrated large amount of strain over the km-thick top-to-the-WNW mylonitic Quiberon extensional shear zone [Gapais et al., 1993]. By accurately constraining the emplacement-age of these plutons within non-melted overriding units, this study retrieved an early increment of the extensional deformation at ca. $321 \pm 3 \mathrm{Ma}$. Cooling and further strain localisation at the roof of leucogranite laccoliths was subsequently recorded by ca. 310-300 Ma Ar/Ar datings (fig. 12) [Ruffet in Le Hébel, 2002; Turrillot, 2010]. By comparison with the French Massif Central, the Brâme leucogranite laccolith [Gébelin et al., 2006, 2009] bounded by the top-to-the-WNW Nantiat mylonitic extensional shear zone [Mollier and Bouchez, 1982; Faure, 1989, 1995; Faure and Pons, 1991], was emplaced syntectonically at ca. $324 \pm 4$ Ma [Holliger et al., 1986]. Active exhumation, strain localization and cooling occur from ca. 320 to $305 \mathrm{Ma}$ including a rapid exhumation stage $(1.5 \mathrm{~mm} / \mathrm{yr})$ at ca. $305 \mathrm{Ma}$ [Scaillet et al., 1996a]. These results reinforce the recognition of a large-scale WNW-ESE strain continuum without significant kinematic change during the exhumation of metamorphic domes from the end of the partial-melting event in the upper amphibolite facies at ca. $320 \mathrm{Ma}$ and continued to near surface brittle faulting until ca. 302-298 Ma controlling the sedimentation intramontane coal-bearing basins [e.g. Pin and Vielzeuf, 1983; Gébelin et al., 2007]. Similarly, strain localisation over series of major extensional shear zones seem greatly influenced by the emplacement of thin leucogranite laccoliths from ca. 320 Ma [Gapais et al., 1993; Gébelin et al., 2006, 2007, 2009; Turrillot et al., 2011].

Geometry, and in some extent, kinematics and timing of exhumation of migmatite-cored metamorphic domes of the coastal South Armorican domain or even of the western parts French Massif Central are therefore quite comparable [Caen-Vachette et al., 1984; Gapais et al., 1993; Burg and Vanderhaeghe, 1993; Burg et al., 1994; Scaillet et al., 1996b; Ledru et al., 2001; Vanderhaeghe et al., 2001; Cagnard et al., 2004; Gébelin et al., 2006, 2007, 2009; Turrillot, 2010; Turrillot et al., 2011a]. Besides, as constrained by emplacement ages of synkinematic plutons and both cooling and deformation ages (see synthesis on figure 12) [Turrillot, 2010; Augier et al., 2011; Tartèse et al., 2011 a; 2011b, 2012], dextral displacement along the South Armorican shear zone 


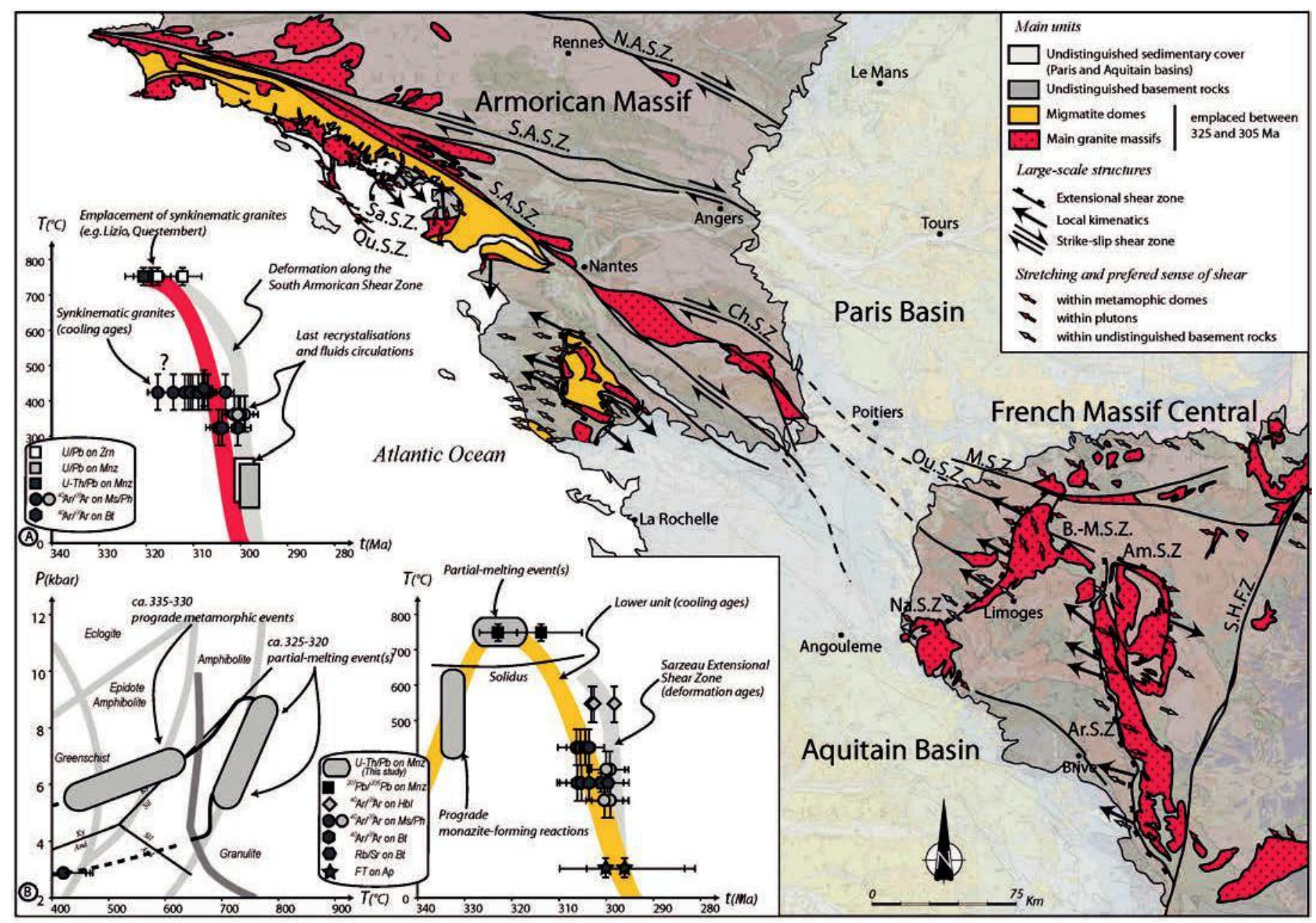

FIG. 12. - Correlations between Armorican massif and the French Massif Central. Particularly highlighted are correlations of wrench and extensional shear zo-nes, (leuco-) granite massifs and metamorphic domes (inspired by Gébelin et al. [2007]; data are from Autran and Lameyre [1980]; Faure [1989, 1995]; Faure and Pons [1991]; Goujou [1992]; Cagnard et al. [2004]; Gébelin et al. [2006, 2007, 2009]; Turrillot et al. [2011a, 2011b] and unpublished data from our team). Qu.S.Z Quiberon shear zone; Sa.S.Z.: Sarzeau shear zone; N.A.S.Z.: North Armorican shear zone; S.A.S.Z.: South Armorican shear zone; Ch.S.Z.: Cholet shear zone; B.M.S.Z.: Bussière-Madelène shear zone; Ou.S.Z.: Ouzilly shear zone; M.S.Z.: Marche shear zone; Am.S.Z.: Ambrugeat shear zone; S.H.F.Z.: Sillon Houiller fault zone. (b) Deformation ages and inferred T-t evolution of the South Armorican shear zone and the associated synkinematic gra-nites. U/Pb ages on zircon (zrn) and monazite (Mnz) are from Tartèse et al. [2011a, 2011b, 2012]; ${ }^{40} \mathrm{Ar} /{ }^{39}$ Ar time-constraints on muscovite, phengite (Ph) and biotite (Bt) from Ruffet in Le Hébel [2002], Tartèse et al. [2011a, 2011b], Turrillot [2010] and Augier et al. [2011]. (c) P-T-t evolution and inferred T-t evolu-tion of the migmatites of the Golfe du Morbihan area from prograde to final cooling stages. Quantitative P-T path where obtained by MnNCKFMASH pseudo-section modelling [Johnson and Brown, 2004]. Metamorphic facies are after Spear [1993]. ${ }^{207} \mathrm{~Pb} /{ }^{206} \mathrm{~Pb}$ ages on monazite (Mnz) are from Peucat [1983]; ${ }^{40} \mathrm{Ar} /{ }^{39} \mathrm{Ar}$ time-constraints on hornblende (Hbl), phengite $(\mathrm{Ph})$ and biotite $(\mathrm{Bt})$ from Brown and Dallmeyer [1996] and Turrillot et al. [2011a]; Rb/Sr on biotite (Bt) data from Peucat [1983]; apatite (Ap) fissiontrack (FT) ages from Carpena et al. [1979]. Available geochronological time-constraints on the Sarzeau ex-tensional shear zone mylonites are given for comparison (see details in Turrillot et al. [2011a]). Mineral abbreviations are after Whitney and Evans [2010].

appears coeval with extensional tectonics. The common WNW-ESE stretching and the dominant top-to-the-WNW kinematics of the extensional deformation thus imply an overall post-thickening northwestward non-rigid motion of the internal zones with respects to the non-thickened Cen-tral Armorican domain controlled by the South Armorican shear zone. It is therefore tempting to propose that the dextral motion over the South Armorican shear zone would be as a major orogeny-parallel transfer zone as initially pro-posed by Gapais et al. [1993]. Furthermore, non-rigid tec-tonic escape does imply a free-boundary to the northwest of the orogenic system that may have played a major role in the formation, or at least to the amplification of the Ibero-Armorican arc. Constraints on the full spatial extent of ca. 320-300 Ma extensional tectonics as well as better, understanding of the orocline formation, still remain to be achieved and requiring integration at the scale of the Variscan belt.

Acknowledgements. - This paper is a contribution in the scientific context of the ERC Rheolith Project and Labex Voltaire (ANR-10-LABX-100-01) projects. We would like to acknowledge particularly Laurent Jolivet, co-PI of the ERC project for discussions at various stages of this work. Financial support for this study was provided by the national 1: 50,000 mapping program of France, by the ISTO-BGRM co-operation in the course of the Paul Turrillot's PhD and by the ERC Rheolith Project. We are indebted to the editor $\mathrm{O}$. Lacombe and the invited editor P. Barbey together with M. Ballèvre and $\mathrm{O}$. Vanderhaeghe for their constructive reviews that have greatly helped to improve the manuscript. The authors are grateful to P. Jézequel (BRGM) for the mineral separation, to S. Janiec and J.G. Badin (ISTO) for the preparation of thin sections of variably weathered samples and to O. Rouer and I. Di Carlo (ISTO) for their assistance during the nu-merous electron microprobe sessions.

SGF guest editor : Pierre Barbey. 


\section{References}

Arzi A. A. (1978). - Critical phenomena in the rheology of partially mel-ted rocks. - Tectonophysics, 44, 173-184.

Augier R., Menier D., Van Vliet-Lanoë B., Hallégouët B., Chauris L., TurRillot P. \& Thinon I. (2011). - Notice explicative de la carte géologique de la France au 1/50 000, feuille Vannes-Saint-Gildas de Rhuys (417). - Orléans, BRGM, 272 p.

AudREn C. (1987). - Evolution structurale de la Bretagne méridionale au Paléozoïque. - Unpublished State Thesis, Université de Rennes, Rennes, France, 366 p.

Audren C. \& Plaine J. (1986). - Notice explicative de la carte géologique de la France au 1/50 000, feuille Belle-Ile-en-Mer - Iles Houat et Hoedic (477). - Orléans, BRGM, 27p.

Audren C. \& Le Métour J. (1976). - Mobilisation anatectique et déformation, un exemple: les migmatites du golfe du Morbihan (Bre-tagne méridionale). - Bull. Soc. géol. Fr., XVIII, 4, 1041-1049.

Audren C. \& Triboulet C. (1993). - P-T-t-deformation paths recorded by kinzigites during diapirism in the western Variscan belt (Golfe du Morbihan, southern Brittany, France). - J. Metam. Geol., 11, 337 356.

Audren C., Triboulet C., Chauris L., Lefort J.-P., Vigneresse J.-C., Audrain J., Thiéblemont D., Goyallon J., Jégouzo P., Guennoc P., Augris C. \& CARn A. (1997). - Notice explicative de la carte géologique de la France au 1/25 000, feuille Île-de-Groix (415). Orléans, BRGM, 34p.

Autran A. \& Lameyre J. (1980). - Conclusions générales. In : A. Autran \& J. LAMEYRE, Eds, Les granitoïdes de France. - Mém. BRGM, 107, 87-99.

BALlÈVRe M. (2007). - Palaeozoic evolution of the Armorican massif: from Gondwana break-up to continental collision. Mechanics of Variscan orogeny: a modern view on orogenic research. - Géol. France, 2, 23-36.

Ballèvre M., Marchand J., Godard G., Goujou J.-C. \& Wyns R. (1994). Eo-Hercynian events in the Armorican massif. In: J.D. KePPIE, Ed., Pre-Mesozoic geology in France and related areas. - Berlin, Springer-Verlag, 1, 183-194.

Ballèvre M., Pitra P. \& Bohn M. (2003). - Lawsonite growth in the epi-dote blueschists from the Ile de Groix (Armorican massif, France): a potential geobarometer. - J. Metam. Geol., 21 (7), 723-735.

Ballèvre M., Bosse V. \& Pitra P. (2007). - Geology, petrology and geochronology of the blueschists from the Île-de-Groix. - International Eclogite Field Symposium (Lochalsh, Scotland), PostSymposium Excursion, $84 \mathrm{p}$.

Ballèvre M., Bosse V., Ducassou C. \& Pitra P. (2009). - Palaeozoic history of the Armorican massif: models for the tectonic evolution of the suture zones. - C. R. Géoscience, 341 (2), 174-201.

BARRoIs C. (1883). - Sur les amphibolites à glaucophane de l'île de Groix. - Bull. Soc. Fr. Minéral. Cristall., 6, 216-218

Be MÉzème E. (2005). - Contribution de la géochronologie U-Th-Pb sur monazite à la compréhension de la fusion crustale dans la chaîne varisque française et implication géodynamique. - Unpublished $\mathrm{PhD}$ Thesis, Université d'Orléans, Orléans, France, 387p.

Be Mézème E., Cocherie A., Faure M., Legendre O. \& Rossi P. (2006). Electron microprobe monazite geochronology of magmatic events: examples from Variscan migmatites and granitoids, Mas-sif Central, France. - Lithos, 87, 276-288

Bechennec F., Hallegouet B., Thieblemont D. \& Thinon I. (2012) - Notice explicative de la carte géologique de la France au 1/50 000, feuille Lorient (383). - Orléans, BRGM, 206 p.

Bernard-Griffiths J., Carpenter M.S.N., Peucat J.-J., \& Jahn B.M. (1986). - Geochemical and isotopic characteristics of blueschist facies rocks from the Ile de Groix, Armorican massif (northwest France). - Lithos, 19 (3), 235-253.

Berthé D., Choukroune P. \& Jegouzo P. (1979). - Orthogneiss, mylonite and non-coaxial deformation of granites: the example of the South Armorican shear zone. - J. Struct. Geol., 1, 31-42.

Bitri A., Brun J.-P., Gapais D., Cagnard F., Gumiaux C., Chantraine J. \& TRUfFERT C. (2010). - Deep reflection seismic imaging of the internal zone of the South Armorican Hercynian belt (western France) (ARMOR 2/Géofrance 3D Program). - C. R. Geos-cience, 342 (6), 448-452.
Bosse V., Féraud G., Ruffet G., Ballèvre M., Peucat J.-J. \& de Jong K (2000). - Late Devonian subduction and early orogenic exhumation of eclogite-facies rocks from the Champtoceaux complex (Variscan belt, France). - Geol. J., 35, 297-325.

Bosse V., Ballèvre M. \& Vidal O. (2002). - Ductile thrusting recorded by the garnet isograd from blueschist-facies metapelites of the Ile de Groix, Armorican massif, France. -J. Petrol., 43 (3), 485-510.

Bosse V., Féraud G., Ballèvre M., Peucat J.-J. \& Corsini M. (2005). $\mathrm{Rb} / \mathrm{Sr}$ and ${ }^{40} \mathrm{Ar} /{ }^{39} \mathrm{Ar}$ ages in blueschists from the île-de-Groix (Armorican Massif, France): Implications for closure mecha-nisms in isotopic systems. - Chem. Geol., 220, 21-45.

BossiÈre G. (1988). - Evolutions chimico-minéralogiques du grenat et de la muscovite au voisinage de l'isograde biotite-staurotide dans un métamorphisme prograde de type barrovien: un exemple en Vendée littorale (Massif armoricain). - C. R. Acad. Sci., Paris, II, 306 (2), $135-140$.

Bouchez J.-L., Guillet P. \& Chevalier F. (1981). - Structures d'écoule-men liées à la mise en place du granite de Guérande (Loire-Atlantique, France). - Bull. Soc. géol. Fr., 7, XXIII, 4, 387-399.

Braun I., Montel J.-M. \& Nicollet C. (1998). - Electron microprobe da-ting of monazite from high-grade gneisses and pegmatites of the Kerala Khondalite belt, southern India. - Chem. Geol., 146, 65-85.

Brillanceau A. (1978). - Guide géologique régional Poitou-Vendée-Charente. - Masson, Paris, France, 124p.

Brown M. (1973). - The definition of metatexis, diatexis and migmatite. Proc. Geol. Ass., 84, 371-378.

BRown M. (1983). - The petrogenesis of some migmatites from the presqu'île de Rhuys, southern Brittany, France. In : M.P. ATHERTON \& C.D. GRIBbLE, Eds, Migmatites, melting and metamorphism. - Shiva Publishing, Nantwich, 174-200.

BRown M. (1994). - The generation, segregation, ascent and emplacement of granite magma: the migmatite-to-crustally-derived granite connection in thickened orogens. - Earth-Sci. Rev., 36, 83-130.

BRown M. (2001). - Orogeny, migmatites and leucogranites: a review. - $J$. Earth Syst. Sci., 110, 313-336.

BRown M. (2005). - Synergistic effects of melting and deformation: an example from the Variscan belt, western France. In : D. GAPAIS, J.P. BRUN \& P.R. CoBbold, Eds., Deformation mechanisms, rheology and tectonics: from minerals to the lithosphere. - Geol. Soc. London, Sp. Publ., 243 (1), 205-226.

Brown M. \& Dallmeyer R. D. (1996). - Rapid Variscan exhumation and the role of magma in core complex formation: southern Brittany metamorphic belt, France. - J. Metam. Geol., 14, 361-379.

BRUN J.-P. \& BURG J.-P. (1982). - Combined thrusting and wrenching in the Ibero-Armorican arc: a corner effect during continental colli-sion. Earth Planet. Sci. Lett., 61, 319-332.

BURG J.-P. (1981). - Tectonique tangentielle hercynienne en Vendée litto-rale: signification des linéations d'étirement E-W dans les por-phyroïdes à foliation horizontale. - C. R. Acad. Sci., Paris, II, 293, 849-854.

Burg J.-P., Bale P., Brun J.-P. \& Girardeau J. (1987). - Stretching linea-tion and transport direction in the Ibero-Armorican arc during the Siluro-Devonian collision. - Geodin. Acta, 1 (1), 71-87.

BuRg J.-P., VAN Den Driessche J. \& BRUN J.-P. (1994). - Syn-to post-thickening extension: mode and consequences. $-C$. R. Acad. Sci., II, 319 (9), 1019-1032.

Caen-Vachette M., Gay M., Peterlongo J.M., Pitiot P. \& Vitel G. (1984) - Age radiométrique du granite syntectonique du Gouffre d'Enfer et du métamorphisme hercynien dans la série de basse pression du Pilat (Massif central français). - C. R. Acad. Sci., II, 299 (17), 12011204

Cagnard F., Gapais D., Brun J.-P., Gumiaux C. \& Van Dan Driessche J. (2004). - Late pervasive crustal-scale extension in the south Armorican Hercynian belt (Vendée, France). - J. Struct. Geol., 26, 435-449. 
Cannat M. \& Bouchez J.-L. (1986). - Linéations N-S en Vendée littorale (Massif armoricain) ; épisodes tangentiels successifs éo-hercy-niens en France occidentale. - Bull. Soc. géol. Fr., 8, II, (2), 299-310.

Carpena J., Chaillou D., Chambodet A. \& Poupeau G. (1979). - Fission track geochronology of the Hercynian platform in France. - Re-port of the 10th International Conference on Solid State Nuclear Track Detectors. - Space Biophysics of the Parliament of the Council of Europe, Lyon.

CARPENTER M.S.N. (1976). - Hercynian high pressure/low metamorphism temperature in the Ile de Groix blueschists. - Nature, 262, 276-277.

Carron J.-P., De Kerneizon M.L.G. \& Nachit H. (1994). - Variscan granites from Brittany. In : W.C. Dullo \& H. NACHIT, Eds, Pre-Mesozoic geology in France and related areas. - Springer, Berlin Heidel-berg, Germany, 5, 231-239.

CARTIER C. \& FAURE M. (2004). - The Saint-Georges-sur-Loire olistos-trome, a key zone to understand the Gondwana-Armorica boun-dary in the Variscan belt (southern Brittany, France). - Internat. J. Earth Sci., 93, 945-958.

Cartier C., Faure M. \& Lardeux H. (2001). - The Hercynian orogeny in the South Armorican massif (Saint-Georges-sur-Loire unit, Li-gerian domain, France): rifting and welding of continental stri-pes. - Terra Nova, 13, 143-149.

Cherniak D.J., Watson E.B., Grove M. \& Harrison T.M. (2004). - Pb diffusion in monazite: a combine RBS/SIMS study. - Geochem. Cosmochim. Acta, 68, 829-840.

Choulet F., Faure M., Fabbri O. \& Monié P. (2012). - Relationships between magmatism and extension along the Autun-La Serre fault system in the Variscan belt of the eastern French Massif Central. Internat. J. Earth Sci., 101 (2), 393-413.

Cogné J. (1949). - Quelques observations tectoniques sur les schistes cristallins et les granites de la Cornouaille maritime. - C. R. Acad. Sci., Paris, 229 (23), 1251-1253.

Cogné J. (1974). - Le Massif armoricain. - Géol. Fr., 1, 105-161.

Cogné J., Horrenberger J.-C. \& Morzadec J. (1986). - Notice explica-tive de la carte géologique de la France au 1/50 000, feuille Lo-rient (383). - Orléans, BRGM, 19p.

Colchen M. \& Poncet D. (1987). - Sur l'âge post-tournaisien de la tectonique hercynienne synschisteuse à Brétignoles-sur-Mer, Vendée littorale, Massif armoricain. - C. R. Acad. Sci., II, 305 (15), 12551258.

Cocherie A. \& Albarede F., (2001). - An improved U-Th-Pb age calcula-tion for electron microprobe dating of monazite. - Geochim. Cosmochim. Acta, 65, 4509-4522.

Cocherie A, Legendre O, Peucat J.-J. \& Kouamelan A.N. (1998). Geochronology of polygenetic monazites constrained by in situ electron microprobe Th-U-total $\mathrm{Pb}$ determination: implications for lead behaviour in monazite. - Geochim. Cosmochim. Acta, 62, 2475-2497.

Cocherie A., Be Mezeme, E., Legendre O., Fanning C.M., Faure M. \& Rossi P. (2005). - Electron-microprobe dating as a tool for determining the closure of $\mathrm{Th}-\mathrm{U} / \mathrm{Pb}$ systems in migmatitic monazi-tes. - Am. Mineral., 90, 607-618.

Choulet F., Faure M., FabBri O. \& Monié P. (2012). - Relationships between magmatism and extension along the Autun-La Serre fault system in the Variscan belt of the eastern French Massif Central. - Internat. J. Earth Sci., 101, 393-413.

Daniel J.M. \& Jolivet L. (1995). - Detachment faults and pluton emplacement; Elba Island (Tyrrhenian Sea). - Bull. Soc. géol. Fr., 166, 341354.

DuchÊNE S., Aissa R., \& VANDERhaeghe O. (2006). - Pressure-tempera-turetime evolution of metamorphic rocks from Naxos (Cycla-des, Greece): Constraints from thermobarometry and $\mathrm{Rb} / \mathrm{Sr}$ dating. Geodin. Acta, 19, 301-321.

England P.C. \& Thompson A. (1986). - Some thermal and tectonic models for crustal melting in continental collision zones. In : M.P. CowARD \& A.C. Ries, Eds., Collision tectonics. - Geol. Soc. London, Sp. Publ., 19, 83-94.

El Korh A. (2010). - Geochemical fingerprints of devolatilization reac-tions in the high-pressure rocks of Ile de Groix, France. - Unpu-blished $\mathrm{PhD}$ Thesis, University of Geneva, Geneva, Switzerland. 319p.
El Korh A., Schmidt S.T., Ballèvre M., Ulianov A. \& Bruguier O. (2012) - Discovery of an albite gneiss from the Ile de Groix (Armorican massif, France): geochemistry and LA-ICP-MS U-Pb geochronology of its Ordovician protolith. - Internat. J. Earth Sci. 101 (5), 1169-1190.

FAMIN V. \& MichON L. (2010). - Volcano destabilization by magma injections in a detachment. - Geology, 38 (3), 219-222.

FAURE M. (1989). - L'amincissement crustal dans la chaîne varisque à par-tir de la déformation ductile des leucogranites du Limousin. $-C$. $R$. Acad. Sci., Paris, II, 309, 1839-1845.

FAURE M. (1995). - Late Carboniferous extension in the Variscan French Massif Central. - Tectonics, 14, 132-153.

FAure M. \& Pons J. (1991). - Crustal thinning recorded by the shape of the Namurian-Wesphalian leucogranite in the Variscan Belt of the northwest Massif Central, France. - Geology, 19, 730-733.

Faure M., Be-Mezeme E., Duguet M., Cartier C. \& Talbot J.Y. (2005). Paleozoic tectonic evolution of medio-Europa from the example of the French Massif Central and Massif Armoricain. - J. Virt. Expl., 19, 1-26.

Faure M., Sommers C., Meleton J., Cocherie A. \& Lautout O. (2008a). The Léon domain (French Massif Armoricain): a westward extension of the Mid-German Crystalline rise? Structural and geochronological insights. - Internat. J. Earth Sci., doi 10.1007/ s00531-008-0360-X.

Faure M., Be Mezeme E., Cocherie A., Rossi P., Chemenda A. \& Boute-lier D. (2008b). - Devonian geodynamic evolution of the Varis-can belt, insights from the French Massif Central and Massif Armoricain. Tectonics, 27 (2), TC2005.

Faure M., Cocherie A., Be Mezeme E. B., Charles N. \& Rossi P. (2010). - Middle Carboniferous crustal melting in the Variscan belt: New insights from $\mathrm{U}-\mathrm{Th}-\mathrm{Pb}$ tot. monazite and $\mathrm{U}-\mathrm{Pb}$ zircon ages of the Montagne Noire Axial zone (southern French Massif Cen-tral). Gondw. Res., 18 (4), 653-673.

FöRSTER H.J. (1998). - The chemical composition of REEY- Th-U-rich accessory minerals in peraluminous granites of the ErzgebirgeFichtelgebirge region, Germany, Part I: The monazite (Ce)-brabantite solid solution series. - Am. Mineral., 83, 259-272.

Förster H.J., Harlov D.E. \& Milke R. (2000). - Composition and Th-U-tota $\mathrm{Pb}$ ages of huttonite and thorite from Gillespie's beach, South Island, New Zealand. - The Can. Mineral., 38, 675-684.

Foster G., Gibson H.D., Parrish R., Horstwood M., Fraser J. \& Tindle A (2002). - Textural, chemical and isotopic insights into the na-ture and behaviour of metamorphic monazite. - Chem. Geol., 191, 183207.

Foster G. \& PARRISH R.R. (2003). - Metamorphic monazite and the generation of PTt paths. In : D. VANCE, W. MÜLLER \& I.M. VILLA, Eds., Geochronology: Linking the isotopic record with petrology and textures. - Geol. Soc. London, Sp. Publ., 220 (1), 25-47.

Gagné S., Jamieson R.A., MacKay R., Wodicka N. \& Corrigan D. (2009). Texture, composition, and age variations in monazite from the lower amphibolite to the granulite facies, Longstaff Bluff Formation, Baffin Island, Canada. - The Can. Mineral., 47 (4), 847 869.

Gapais D., Lagarde J.-L., Le Corre C., Audren C., Jégouzo P., Casas Sains A. \& VAN Den Driessche J. (1993). - La zone de cisaille-ment de Quiberon: témoin d'extension de la chaîne Varisque en Bretagne méridionale au Carbonifère. - C. R. Acad. Sci., Paris, II, 316, 1123 1129.

Gapais D., Cagnard F., Gueydan F., Barbey P. \& Ballèvre M. (2009). Mountain building and exhumation processes through time: inferences from nature and models. - Terra Nova, 21 (3), 188-194.

Gardes E., Jaoul O., Montel J.-M., Seydoux-Guillaume A.-M. \& Wirth R. (2006). - $\mathrm{Pb}$ diffusion in monazite: An experimental study of $\mathrm{Pb}^{2++} \mathrm{Th}^{4+} 2 \mathrm{Nd}^{3+}$ interdiffusion. - Geochim. Cosmochim. Acta, 70 (9), 2325-2336

Gardien V., Lardeaux J.-M., Ledru P., Allemand P. \& Guillot S. (1997). Metamorphism during late orogenic extension; insights from the French Variscan belt. - Bull. Soc. géol. Fr., 168 (3), 271-286.

Gébelin A., Martelet G., Chen Y., Brunel M. \& Faure M. (2006). Structure of late Variscan Millevaches leucogranite massif in the French Massif Central: AMS and gravity modelling results. - J. Struct. Geol., 28 (1), 148-169. 
Gébelin A., Brunel M., Monié P., Faure M. \& Arnaud N. (2007). Transpressional tectonics and Carboniferous magmatism in the Limousin, Massif Central, France: structural and ${ }^{40} \mathrm{Ar} /{ }^{39} \mathrm{Ar}$ investigations. - Tectonics, 26, doi: 10.1029/2005TC001822.

GÉbelin A., Roger F. \& BRUNEL M. (2009). - Syntectonic crustal melting and high-grade metamorphism in a transpressional regime, Variscan Massif Central, France. - Tectonophysics, 477 (3), 229-243.

GeOFrRoy L. (1993). - Tectonique tardi-varisque en failles normales ducti-les en Vendée littorale, Massif armoricain. - C. R. Acad. Sci., Paris, II, 317 (9), 1237-1243.

GloAguen E. (2006). - Apports d'une étude intégrée sur les relations entre granites et minéralisations filoniennes ( $\mathrm{Au}$ et $\mathrm{Sn}-\mathrm{W})$ en contexte tardi-orogénique (Chaîne hercynienne, Galice centrale, Espagne). Unpublished PhD Thesis, Université d'Orléans, Orléans, France, $523 \mathrm{p}$.

Goncalves P., Nicollet C. \& Montel J.-M. (2004). - Petrology and in situ $\mathrm{U}-\mathrm{Th} / \mathrm{Pb}$ monazite geochronology of ultrahigh-temperature metamorphism from the Andriamena mafic unit, north-central Madagascar. Significance of a petrographical P-T path in a polymetamorphic context. - J. Petrol., 45, 1923-1957, doi: 10.1093/ petrology/egh041

Goujou J.-C. (1992). - Analyse pétro-structurale dans un avant-pays métamorphique: influence du plutonisme tardi-orogénique varisque sur l'encaissant épi à mésozonal de Vendée. - Unpublished PhD Thesis, BRGM, Orléans, France, 216p.

Goujou J.-C., Debrand-Passard S., HantzPergue P. \& Lebret P. (1994). Notice explicative de la carte géologique de la France au 1/50 000, feuille Les Sables d'Olonne (584). - Orléans, BRGM, 95p.

Grasemann B. \& Petrakakis K. (2007). - Evolution of the Serifos metamorphic core complex. - J. Virt. Expl., 27 (2), doi: 10.3809/jvirtex.2007.00170.

Guillet P., Bouchez J.-L. \& Wagner J.J. (1983). - Anisotropy of magne-tic susceptibility and magmatic structures in the Guérande gra-nite massif (France). - Tectonics, 2 (5), 419-429.

Guiraud M., Burg J.-P. \& Powell R. (1987). - Evidence for a Variscan suture zone in the Vendée, France: a petrological study of blues-chist facies rocks from Bois de Céné. - J. Metam. Geol., 5 (2), 225-237.

Gumiaux C., Gapais D., Brun J.-P., Chantraine J. \& Ruffet G. (2004). Tectonic history of the Hercynian Armorican shear belt (Britta-ny, France). - Geodin. Acta, 17 (4), 289-307.

Hawkins D.P. \& Bowring S.A. (1999). - U-Pb monazite, xenotime and titanite geochronological constraints on the prograde to post-peak metamorphic thermal history of Paleoproterozoic migmatites from the Grand Canyon, Arizona. - Contrib. Mineral. Petrol., 134 (2-3), 150-169.

Hinchey A.M., Carr S.D., McNeill P.D. \& Rayner N. (2006). - Paleo-ceneEocene high-grade metamorphism, anatexis, and deforma-tion in the Thor-Odin dome, Monashee complex, southeastern British Columbia. - Can. J. Earth Sci., 43 (9), 1341-1365.

Holliger P., Cuney M., Friedrich M. \& TurPin L. (1986). - Age carboni-fère de l'unité de Brâme du complexe granitique peralumineux de St Sylvestre (NW du Massif central) défini par les données isotopiques U-Pb sur zircon et monazite. - C. R. Acad. Sci., Paris, 303, 13091314.

Houseman G. (1988). - The dependence of convection planform on mode of heating. - Nature, 332, 346-349, doi: 10.1038/332346a0.

HutTon D.H.W. (1982). - A tectonic model for the emplacement of the Main Donegal granite, NW Ireland. - J. Geol. Soc. London, 139, 615631.

IgLESIAS M. \& BRUN J.-P. (1976). - Signification des variations et anoma-lies de la déformation dans un segment de la chaîne hercynienne (les séries cristallophylliennes de la Vendée littorale, Massif armoricain). - Bull. Soc. géol. Fr., 7, XVIII, 6, 1443-1452.

Janots E., Engi M., Rubatto D., Berger A., Gregory C. \& Rahn M. (2009). - Metamorphic rates in collisional orogeny from in situ allanite and monazite dating. - Geology, 37, 11-14.

JÉGouzo P. (1980). - The South Armorican shear zone. - J. Struct. Geol., 2, 39-47.

JÉGouzo P. \& Rossello E. A. (1988). - La branche nord du Cisaillement sudarmoricain (France): un essai d'évaluation du déplacement par l'analyse des mylonites. - C. R. Acad. Sci., Paris, II, 307 (17), 1825-1831.
JOHNSON T. \& BROwN M. (2004). - Quantitative constraints on metamor-phism in the Variscides of southern Brittany - a complementary pseudosection approach. - J. Petrol., 45, 1237-1259.

Jolivet L. \& Brun J.-P. (2010). - Cenozoic geodynamic evolution of the Aegean. - Internat. J. Earth Sci., 99 (1), 109-138.

Jolivet L., Lecomte E., Huet B., Denèle Y., Lacombe O., Labrousse L. \& MeHL C. (2010). - The north cycladic detachment system. Earth Planet. Sci. Lett., 289 (1), 87-104.

JoNES K.A. (1991). - Paleozoic continental margin tectonics of southern Armorica. - J. Geol. Soc. London, 148, 55-64.

JoNES K.A. \& BRown M. (1989). - The metamorphic evolution of the southern Brittany migmatite belt. In : J.S. DALY, R.A. CLIFF \& B.W.D. YARDLEY, Eds., Evolution of metamorphic belts. - Geol. Soc. London, Sp. Publ., 43, 501-505.

JONES K.A. \& BRown M. (1990). - High-temperature 'clockwise' P-T paths and melting in the development of regional migmatites: an example from southern Brittany, France. - J. Metam. Geol., 8, 551-578.

Kelsey D.E., ClaRk C. \& Hand M. (2008). - Thermobarometric model-ling of zircon and monazite growth in melt-bearing systems: Examples using model metapelitic and metapsammitic granuli-tes. $-J$. Metam. Geol., 26 (2), 199-212.

Kohn M.J., Wieland M.S., Parkinson C.D. \& Upreti B.N. (2005). - Five generations of monazite in Langtang gneisses: implications for chronology of the Himalayan metamorphic core. - J. Metam. Geol., 23 (5), 399-406.

Le Corre C. (1977). - Le Briovérien de Bretagne centrale: essai de syn-thèse lithologique et structurale. - Bull. BRGM, 17 (3), 219-254.

Le Corre C., Auvray B., Ballèvre M. \& Robardet M. (1991). - Le Mas-sif armoricain. - Sci. Géol. Bull., 44 (1-2), 31-103.

Ledru P., Courrioux G., Dallain C., Lardeaux J.-M., Montel J.-M., VAnderhaeghe O. \& Vitel G. (2001). - The Velay dome (French Massif Central): melt generation and granite emplacement du-ring orogenic evolution. - Tectonophysics, 342 (3), 207-237.

LE HÉBEL F. (2002) - - Déformation continentale et histoire des fluides au cours d'un cycle subduction, exhumation, extension. Exemple des porphyroïdes sud-armoricains. - Unpublished $\mathrm{PhD}$ Thesis, Université de Rennes I, Rennes. 321 p.

Le Hébel F., Gapais D., Fourcade S. \& Capdevila R. (2002a). - Fluid-assisted large strains in a crustal-scale decollement (Hercynian belt of south Brittany, France). - Geol. Soc., Sp. Publ., 200, 85-101.

Le Hébel F., Vidal O., Kienast J.-R. \& Gapais D. (2002b). - Les « porphyroïdes » de Bretagne méridionale: une unité de HP-BT dans la chaîne hercynienne. - C. R. Géoscience, 334, 205-211.

Linthout K. (2007). - Tripartite division of the system 2REEPO4-CaTh (PO4)2-2ThSiO4, discreditation of brabantite, and recognition of cheralite as the name for members dominated by CaTh (PO4)2. The Can. Mineral., 45 (3), 503-508.

LUDWIG K.R. (2003). - User's manual for Isoplot 3.00. A geochronological toolkit for Microsoft Excel. - Berkeley Geochronology Center, 70 p.

Maillet D. (1984). - Relations des porphyroïdes et schistes de Saint-Gilles avec les formations siluriennes de Brétignolles-Sur-Mer (Vendée Maritime). - Unpublished PhD Thesis, Université de Rennes I, Rennes, France. 256 p.

Majka J., Be’eri-Shlevin Y., Ladenberger A., Claesson S., Konecny P., KLONOWSKA I. \& GEE D.G. (2012). - Multiple monazite growth in the Åreskutan migmatite: evidence for a polymetamorphic Caledonian evolution of the Seve nappe complex in west-central Jämtland, Sweden. - J. Geosci., 57, 3-23.

Marchand J. (1981). - Ecaillage d'un "mélange tectonique" profond: le complexe cristallophyllien de Champtoceaux (Bretagne méridionale). - C. R. Acad. Sci., Paris, 293, 223-228.

Marchildon N. \& Brown M. (2003). - Spatial distribution of melt-bearing structures in anatectic rocks from southern Brittany, France: implications for melt-transfer at grain-scale to orogen-scale. - Tectonophysics, 364, 215-235.

Matte P. (1986). - Tectonics and plate tectonic model for the Variscan belt of Europe. - Tectonophysics, 126, 329-374.

MAtTe P. (1991). - Accretionary history and crustal evolution of the Varis-can belt in western Europe. - Tectonophysics, 196, 309-337. 
MatTe P. (2001). - The Variscan collage and orogeny (480-290 Ma) and the definition of the Armorica microplate: tectonic approach. - Terra Nova, 13, 122-128.

MeHnert K.R. (1968). - Migmatites and the origin of granitic rocks. Elsevier, Amsterdam, the Netherlands, p. 393.

Mollier B. \& Bouchez J.-L. (1982). - Structuration magmatique du complexe granitique de Brâme-St Sylvestre-St Goussaud (Li-mousin, Massif central français). - C. R. Acad. Sci., Paris, II, 294, 1329-1334.

MONTEL J.-M. (1986). - Experimental determination of the solubility of Cemonazite in $\mathrm{SiO}_{2}-\mathrm{Al}_{2} \mathrm{O}_{3}-\mathrm{K}_{2} \mathrm{O}-\mathrm{Na}_{2} \mathrm{O}$ melts at $800^{\circ} \mathrm{C}, 2 \mathrm{kbar}$, under $\mathrm{H}_{2} \mathrm{O}$-saturated conditions. - Geology, 14 (8), 659-662.

Montel J.-M. (1987). - Comportement des terres rares dans les magmas granitiques: modélisation et approche expérimentale du rôle de la monazite. - Unpublished PhD Thesis, Université de ClermontFerrand, Clermont-Ferrand, 347p.

Montel J.-M. (1993). - A model for monazite/melt equilibrium and application to the generation of granitic magmas. - Chem. Geol., 110, 127-146.

Montel J.-M., Devidal J.-L. \& Avignant D. (2002). - X-ray diffraction study of brabantite-monazite solid solutions. - Chem. Geol., 191, 89-104.

Nance R.D., Gutiérrez-Alonso G., Keppie J.D., Linnemann U., Murphy J.B., Quesada C. \& Woodcock N.H. (2010). - Evolution of the Rheic ocean. - Gondw. Res., 17 (2), 194-222.

Nelson K.D., Zhao W., Brown L.D., Kuo J., Che J., Liu X. \& Edwards M. (1996). - Partially molten middle crust beneath southern Tibet: synthesis of project INDEPTH results. - Science, 274, 1684-1688.

Neves S.P., VAuchez A. \& ARChanjo C.J. (1996). - Shear zone-controlled magma emplacement or magma assisted nucleation of shear zones? Insights from northeast Brazil. - Tectonophysics, 262, 349-364.

PARRISH R.R. (1990). - U-Pb dating of monazite and its application to geological problems. - Can. J. Earth Sci., 27 (11), 1431-1450.

Peucat J.-J. (1983). - Géochronologie des roches métamorphiques (Rb-Sr et $\mathrm{U}-\mathrm{Pb}$ ): exemples choisis au Groenland, en Laponie, dans le Massif armoricain et en Grande Kabylie. - Soc. Géol. Minéral. Bretagne, 28, 45-56.

Peucat J.-J., Le Métour J. \& Audren C. (1978). - Arguments géochronologiques en faveur de l'existence d'une double ceinture métamorphique d'âge siluro-dévonien en Bretagne méridionale. - Bull. Soc. géol. Fr., 7, XX, 163-167.

Peucat J.-J., Charlot R., Mifdal A., Chantraine J. \& Autran A. (1979). Définition géochronologique de la phase bretonne en Bretagne centrale. Etude $\mathrm{Rb} / \mathrm{Sr}$ de granites du domaine centre armoricain. Bull. BRGM, 1 (4), 349-356.

Pin C. \& Peucat J.-J. (1986). - Ages des épisodes de métamorphisme paléozoïques dans le Massif central et le Massif armoricain. - Bull. Soc. géol. Fr., 8, II, (3), 461-469.

Pin C. \& Vielzeuf D. (1983). - Granulites and related rocks in Variscan median Europe: a dualistic interpretation. - Tectonophysics, 93 (1), 47-74.

Plaine J., Hallégouët B. \& Quété Y. (1984). - Notice explicative de la carte géologique de la France au 1/50 000, feuille Questembert (418). Orléans, BRGM, 63p.

Pommier A., Cocherie A. \& Legendre O. (2002). - EPMA dating user's manual: age calculation from electron probe microanalyser measurements of U-Th/Pb. - BRGM, Orléans, France.

PYLE J.M. (2006). - Temperature-time paths from phosphate accessory phase paragenesis in the Honey Brook Upland and associated cover sequence, SE Pennsylvania, USA. - Lithos, 88 (1), 201-232.

PYLE J.M. \& SPEAR F.S. (2003). - Four generations of accessory-phase growth in low-pressure migmatites from SW New Hampshire. - Am. Mineral., 88 (2-3), 338-351.

Pyle J.M., Spear F.S., Rudnick R.L. \& McDonough W.F. (2001). - Monazite-xenotime-garnet equilibrium in metapelites and a new monazite-garnet thermometer. - J. Petrol., 42, 2083-2107.

Quinquis H., Audren C.L., Brun J.-P. \& CobBold P.R. (1978). - Intense progressive shear in Ile de Groix blueschists and compatibility with subduction or obduction. - Nature, 7, 43-45, doi: $10.1038 / 273043 \mathrm{a} 0$.

Rey P.F., VAnderhaeghe O. \& Teyssier C. (2001). - Gravitational col-lapse of the continental crust: definition, regimes and modes. Tectonophysics, 342 (3), 435-449.
Rey P.F., Teyssier C. \& Whitney D.L. (2009a). - Extension rates, crustal melting, and core complex dynamics. - Geology, 37 (5), 391-394.

Rey P.F., Teyssier C. \& Whitney D.L. (2009b). - The role of partial-mel-ting and extensional strain rates in the development of metamor-phic core complexes. - Tectonophysics, 477, 135-144, doi: 10.1016/j.tecto.2009.03.010.

Rolin P. \& Colchen M. (2001). - Les cisaillements hercyniens de la Vendée au Limousin. - Géol. Fr., 1-2, 15-44.

Rosenberg C.L. \& HANDY M.R. (2005). - Experimental deformation of partially melted granite revisited: implications for the continen-tal crust. - J. Metam. Geol., 23 (1), 19-28.

Rubatto D., Williams I.S. \& Buick I.S. (2001). - Zircon and monazite response to prograde metamorphism in the Reynolds Range, central Australia. - Contrib. Mineral. Petrol., 140 (4), 458-468.

SAWYER E.W. (1994). - Melt segregation in the continental crust. - Geolo-gy, 22, 1019-1022.

SAWYER E.W. (1999). - Criteria for the recognition of partial-melting. - Phys. Chem. Earth, Part A : Solid Earth and Geodesy, 24, 269-279.

Scaillet S., Cheilletz A., Cuney M., Farrar E., \& Archibald D.A. (1996a). - Cooling pattern and mineralization history of the Saint Sylvestre and western Marche leucogranite pluton, French Massif Central: I. ${ }^{40} \mathrm{Ar} /{ }^{39} \mathrm{Ar}$ isotopic constraints. - Geochim. Cosmochim. Acta, 60, 4653-4671.

Scaillet S., Cuney M., Le Carlier de Veslud C., Cheilletz A. \& Royer J.J. (1996b). - Cooling pattern and mineralization history of the Saint Sylvestre and western Marche leucogranite pluton, French Massif Central: II. Thermal modelling and implications for the mechanisms of U-mineralization. - Geochim. Cosmochim. Acta, 60, 4673-4688.

Seydoux-Gulllaume A.-M., Paquette J.-L., Wiedenbeck M., Montel J.-M. \& HeINRICH W. (2002). - Experimental resetting of the U-Th/Pb systems in monazite. - Chem. Geol., 191 (1), 165-181.

SMith H.A. \& BARREIRo B. (1990). - Monazite U-Pb dating of staurolite grade metamorphism in pelitic schists. - Contrib. Mineral. Pe-trol., 105 (5), 602-615.

Smith H.A. \& Giletti B.J. (1997). - Lead diffusion in monazite. - Geo-chim. Cosmochim. Acta, 61, 1047-1055.

SPEAR F. (1993). - Metamorphic phase equilibria and pressure-tempera-turetime paths. - Book Crafters, Chelsea, Michigan, USA, 70, 456p.

SPEAR F. (2010). - Monazite-allanite phase relations in metapelites. - Chem. Geol., 279, (1-2), 55-62.

SuZUKI K. \& ADACHI M. (1991). - Precambrian provenance and Silurian metamorphism of the Tsubonosawa paragneiss in the South Kitakami terrane, Northeast Japan, revealed by the chemical Th-Utotal $\mathrm{Pb}$ isochron ages of monazite, zircon and xenotime. Geochem. J., 25, 357-376.

Tartèse R., Poujol M., Ruffet G., Boulvais P., Yamato P., \& Kosler J. (2011a). - New U-Pb zircon and ${ }^{40} \mathrm{Ar} /{ }^{39} \mathrm{Ar}$ muscovite age constraints on the emplacement of the Lizio syn-tectonic granite (Armorican massif, France). - C. R. Géoscience, 343, 443-453.

TArtèse R., Ruffet G., Poujol M., Boulvais P. \& Ireland T.R. (2011b). Simultaneous resetting of the muscovite $\mathrm{K}-\mathrm{Ar}$ and monazite $\mathrm{U} / \mathrm{Pb}$ geochronometers: a story of fluids. - Terra Nova, 23, 390-398.

Tartèse R., Boulvais P., Poujol M., Chevalier T., Paquette J.-L., Ireland T.R. \& Deloule E. (2012). - Mylonites of the South Armorican shear zone: Insights for crustal-scale fluid flow and water-rock interaction processes. - J. Geodyn., 56, 86-107.

Ters M. (1972). - Sur l'extension du Paléozoïque en Vendée littorale. Stratigraphie et structure. - C. R. Somm. Soc. géol. Fr., 3, 1146-1148.

TERS M. (1979). - Les synclinoriums paléozoïques et le Précambrien sur la façade occidentale du Massif vendéen. Stratigraphie et structure. Bull. BRGM, 24, 293-301.

Ters M., March J., Chateauneuf J.-J., Visset L., Biteau F., Ottmann F., Limasset O., Talbo H., Guigues J. \& Bambier A. (1978). - Notice explicative de la carte géologique de la France au 1/50 000, feuille Paimboeuf (480). - Orléans, BRGM, 59p.

Tirel C., Brun J.-P. \& Burov E. (2008). - Dynamics and structural development of metamorphic core complexes. -J. Geophys. Res. : Solid Earth, 113 (B4), 1-33. 
Triboulet C. \& Audren C. (1985). - Continuous reactions between biotite, garnet, staurolite, kyanite-sillimanite-andalusite and P-T-time deformation path in micaschists from the estuary of the river Vi-laine, South Brittany, France. - J. Metam. Geol., 3 (1), 91-105.

Triboulet C. \& Audren C. (1988). - Controls on P-T-t deformation path from amphiboles during progressive metamorphism with basic rocks (estuary of the river Vilaine, South Brittany, France). - J. Metam. Geol., 6, 117-133.

Turrillot P. (2010). - Fusion crustale et évolution tardi-orogénique du Domaine sud armoricain. - Unpublished PhD Thesis, Université d'Orléans, Orléans, France. 359 p.

Turrillot P., Augier R. \& Faure M. (2009). - The top-to-the-east Sar-zeau shear zone and its place in the late-orogenic extensional tectonics of southern Armorica. - Bull. Soc. géol. France, 180, (3), 183-196.

Turrillot P., Augier R., Monié P. \& Faure M. (2011a). - Late-orogenic exhumation of the Variscan high-grade units (South Armorican domain, western France), combined structural and ${ }^{40} \mathrm{Ar} /{ }^{39} \mathrm{Ar}$ constraints. - Tectonics, doi: 10.1029/2010TC002788.

Turrillot P., Faure M., Martelet G., Chen Y. \& Augier R. (2011b). Pluton-dyke relationships in a Variscan granitic complex from AMS and gravity modelling. Inception of the extensional tecto-nics in the South Armorican domain (France). - J. Struct. Geol. doi: 10.1016/j.jsg.2011.08.004.

VANDERHAEGHE O. (2004). - Structural development of the Naxos migma-tite dome. In : D. Whitney, C. Teyssier \& C.S. Siddoway, Eds., Gneiss domes in orogeny. - Geol. Soc. Amer., Sp. Pap., Boulder, USA, 211-228.

VANDERHAEGHE O. (2009). - Migmatites, granites and orogeny: Flow mo-des of partially molten rocks and magmas associated with melt/ solid segregation in orogenic belts. - Tectonophysics, 477, 119-134.

VANDERhaEghe O. \& Teyssier C. (2001). - Partial-melting and flow of orogens. - Tectonophysics, 342(3), 451-472.

VANDERhaEghe O., Teyssier C. \& WysocZANSKI R. (1999). - Structural and geochronological constraints on the role of partial-melting during the formation of the Shuswap metamorphic core complex at the latitude of the Thor-Odin dome, British Columbia. - Can. J. Earth Sci., 36 (6), 917-943.
Vanderhaeghe O., Medvedev S., Fullsack P., Beaumont C. \& Jamieson R.A. (2003). - Evolution of orogenic wedges and continental plateaux: insights from crustal thermal-mechanical models overlying subducting mantle lithosphere. - Geophys. J. Internat., 153 27-51

Vauchez A., Maillet D. \& Sougy J. (1987). - Strain and deformation mechanisms in the Variscan nappes of Vendée, South Brittany, France. - J. Struct. Geol., 9 (1), 31-40.

Vavra G., Gebauer D., Schmid R. \& Compston W. (1996). - Multiple zircon growth and recrystallization during polyphase Late Car-boniferous to Triassic metamorphism in granulites of the Ivrea zone (southern Alps): an ion microprobe (SHRIMP) study. - Contrib. Mineral. Petrol., 122 (4), 337-358.

VIDAL P. (1980). - L'évolution polyorogénique du Massif armoricain: ap-port de la géochronologie et de la géochimie isotopique du stron-tium. Mém. Soc. Géol. Minéral. Bretagne, 21, 162 p.

VIGNERESSE J.-L. (1978). - Gravimétrie et granites armoricains: structure et mise en place des granites hercyniens. - Unpublished PhD Thesis, Université de Rennes I, Rennes, France, 147 p.

Vigneresse J.-L., Tikoff B. \& AmÉglio L. (1999). - Modification of the regional stress field by magma intrusion and formation of tabu-lar granitic plutons. - Tectonophysics, 302 (3), 203-224.

WatTs M.S. \& Williams G.D. (1979). - Faults rocks as indicators of progressive shear deformation in the Guingamp region, Brittany. $-J$. Struct. Geol., 1, 323-332.

WENDT I. \& CARL C. (1991). - The statistical distribution of the mean squared weighted deviation. - Chem. Geol., 86, 275-285.

WERNICKE B. (1992). - Cenozoic extensional tectonics of the U.S. Cordil-lera. In : B.C. Burchfiel, P.W. Lipman \& M.L. Zoback, Eds., The Cordilleran orogen: Conterminous U.S. - The Geology of North America. - Geol. Soc. Amer., Sp. Pap., Boulder, USA, 553-581.

WhitNEY D.L. \& Evans B.W. (2010). - Abbreviations for names of rockforming minerals. - Am. Mineral., 95 (1), 185.

Wyns R. \& Le Métour J. (1983). - Le Précambrien du massif vendéen. Etude détaillée de deux coupes de référence (coupe de l'Evre et coupe de la Divatte) et synthèse des données récentes. - Doc. BRGM, 68, 60 . 